University of Michigan Law School

University of Michigan Law School Scholarship Repository

2014

\title{
Racial Disparity in Federal Criminal Sentences
}

\author{
M. Marit Rehavi \\ University of British Columbia and Canadian Institute for Advanced Research, marit.rehavi@ubc.ca \\ Sonja B. Starr \\ University of Michigan Law School, sbstarr@umich.edu
}

Available at: https://repository.law.umich.edu/articles/1414

Follow this and additional works at: https://repository.law.umich.edu/articles

Part of the Civil Rights and Discrimination Commons, Criminal Law Commons, Law and Race Commons, and the Law and Society Commons

\section{Recommended Citation}

Starr, Sonja B. "Racial Disparity in Federal Criminal Sentences." M. M. Rehavi, co-author. J. Pol. Econ. 122, no. 6 (2014): 1320-54.

This Article is brought to you for free and open access by the Faculty Scholarship at University of Michigan Law School Scholarship Repository. It has been accepted for inclusion in Articles by an authorized administrator of University of Michigan Law School Scholarship Repository. For more information, please contact mlaw.repository@umich.edu. 


\title{
Racial Disparity in Federal Criminal Sentences
}

\author{
M. Marit Rehavi
}

University of British Columbia and Canadian Institute for Advanced Research

\section{Sonja B. Starr}

University of Michigan

\begin{abstract}
Using rich data linking federal cases from arrest through to sentencing, we find that initial case and defendant characteristics, including arrest offense and criminal history, can explain most of the large raw racial disparity in federal sentences, but significant gaps remain. Across the distribution, blacks receive sentences that are almost 10 percent longer than those of comparable whites arrested for the same crimes. Most of this disparity can be explained by prosecutors' initial charging decisions, particularly the filing of charges carrying mandatory minimum sentences. Ceteris paribus, the odds of black arrestees facing such a charge are 1.75 times higher than those of white arrestees.
\end{abstract}

\section{Introduction}

Black men constitute 6 percent of the US adult population but are approximately 35 percent of the prison population and are incarcerated at a rate six times that of white males (Carson and Sabol 2012). One in three black men will be incarcerated at some point in his life (Bonczar 2003). The federal prison system is the largest and fastest-growing in the

Rehavi gratefully acknowledges the financial support of the Canadian Institute for Advanced Research, the Peter Wall Institute for Advanced Studies, and the AURA Fund. We thank Bill Adams of the Urban Institute and Mark Motivans of the Bureau of Justice Statistics for their guidance concerning the bureau data and linking files. We thank the editor (Derek Neal), anonymous referees, David Abrams, Joe Altonji, Alan Auerbach, Leonid Feller, Nicole Fortin, Richard Freeman, Nancy Gallini, David Green, Sam Gross, Ing-Haw Cheng, Don Herzog, Jim Hines, Jill Horwitz, Thomas Lemieux, Kevin Milligan, Brendan Nyhan, J. J. Prescott, Eve 
United States (Congressional Research Service 2013). Black male defendants in federal criminal cases receive much longer prison sentences than white men do (fig. 1). In federal courts, the average sentence during 2008 and 2009 was 55 months for whites and 90 months for blacks (US Sentencing Commission 2010). The extent to which these disparities reflect differences in criminal conduct as opposed to differential treatment is a long-standing question in law and economics. That is, do otherwise similar black and white arrestees caught engaging in the same criminal conduct receive different prison sentences?

A key empirical challenge in answering this question is the lack of data on true criminal conduct. Of necessity, previous estimates of racial disparity in prison sentences proxy for criminal conduct with a measure of the severity of the crime of conviction: often the "presumptive sentence," which is the recommended sentence under the applicable sentencing guidelines and takes account of aggravating and mitigating "sentencing facts." However, neither the crime of conviction nor the presumptive sentence is an exogenous measure of criminal conduct. Each is the product of highly discretionary and negotiated processes, including charging, plea bargaining, and sentencing fact-finding. These processes are carried out in expectation of their sentencing consequences and potentially involve racial disparities of their own. Moreover, since the existing literature relies on sentencing data, its samples consist only of sentenced cases and thus potentially suffer from selection bias.

We address both limitations by constructing a linked multiagency data set that follows federal cases from arrest through to sentencing. The data cover the universe of black and white male US citizens who were arrested for violent, property/fraud, weapons, and public order offenses and referred to federal prosecutors for potential prosecution between fiscal years 2006 and 2008. ${ }^{1}$ Using individual records from the US Marshals Service (which collects arrest data), federal prosecutors, federal courts, and the US Sentencing Commission, we constructed a complete picture of each individual's path through the federal justice system. The detailed arrest data provide a proxy for underlying conduct that (while certainly not perfect) is not distorted by discretionary charging, plea bargaining, and fact-finding processes. Combining data from multiple agencies also

\footnotetext{
Brensike Primus, Adam Pritchard, Jeff Smith, Sara Sun-Beale, and participants at the American Law and Economics Association, the American Society of Criminology, the Canadian Institute for Advanced Research, the Canadian Labour Market and Skills Researcher Network, Duke, Loyola, the National Sentencing Policy Institute, the National Bureau of Economic Research, the Ninth Circuit Judicial Conference, and the University of Michigan for extremely helpful comments. Seth Kingery, Sharon Brett, Ryan Gersovitz, Matthew Lee, Sabrina Speianu, and Daniel Shack provided valuable research assistance.

1 The main estimates exclude other categories of crimes (most notably drugs) because of data limitations. More limited analyses of broader samples, including drug cases, find similar racial disparity patterns.
} 


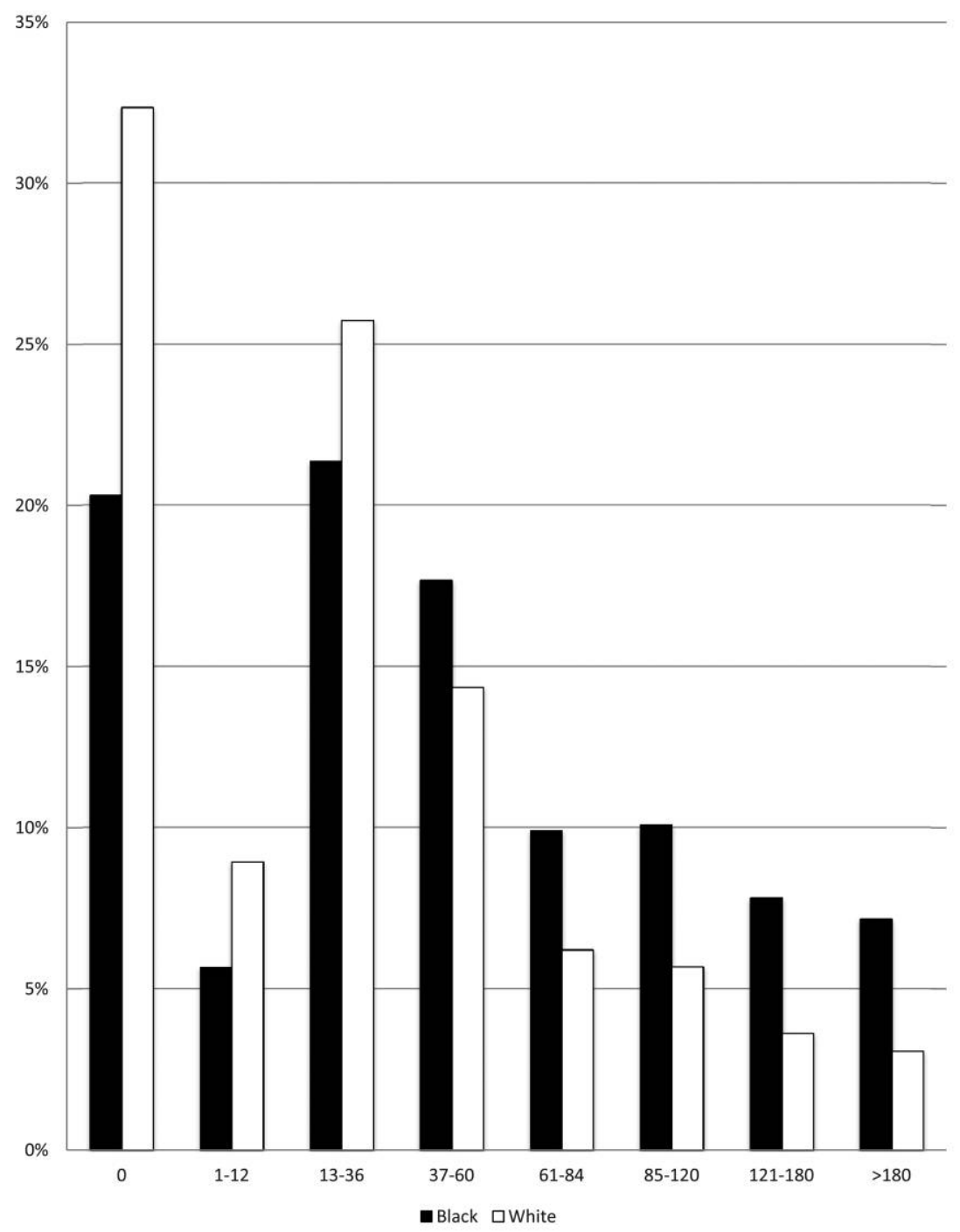

FIG. 1.-Distribution of prison sentences by race (months)

provides a rich picture of the characteristics of the offender and the offense. These data allow us to compare the sentencing outcomes for black and white men who are arrested for the same offenses and appear comparable when they enter the federal justice system. We thus estimate the extent to which observed racial disparities in federal sentences can be explained by differences in arrest offense characteristics and preexisting defendant characteristics such as criminal history. 
Using quantile regressions, we estimate the size of racial disparity across the conditional sentencing distribution. We find that the majority of the disparity between black and white sentences can be explained by differences in legally permitted characteristics, in particular, the arrest offense and the defendant's criminal history. Black arrestees are also disproportionately concentrated in federal districts that have higher sentences in general. Yet even after we control for these and other prior characteristics, an unexplained black-white sentence disparity of approximately 9 percent remains in our main sample. The disparity is nearly 13 percent in a broader sample that includes drug cases. Estimates of the conditional effect of being black on sentences are robust, fairly stable across the deciles, and economically significant. There are approximately 95,000 black men in federal prisons. Eliminating the "black premium" that we identify would reduce the steady-state level of black men in federal prison by 8,000-11,000 men and save \$230-\$320 million per year in direct costs.

Observing each case from arrest through to sentencing makes it possible to pinpoint where unexplained disparities emerge in the judicial process. We identify an important procedural mechanism that appears to give rise to the majority of the otherwise-unexplained disparity in sentences: how prosecutors initially choose to handle the case, in particular, the decision to bring charges carrying "mandatory minimum" sentences. The racial disparities in this decision are stark: ceteris paribus, black men have 1.75 times the odds of facing such charges, which is equivalent to a 5 percentage point (or 65 percent) increase in the probability for the average defendant. The initial mandatory minimum charging decision alone is capable of explaining more than half of the black-white sentence disparities not otherwise explained by precharge characteristics.

These differences in initial charging highlight the importance of using proxies for alleged criminal conduct that are not themselves a product of the federal judicial process. Sentence disparity estimates that condition on the presumptive sentence or other features of the crime of conviction are problematic because those measures are determined through discretionary processes and negotiations that may contain racial disparities. By focusing on the judge's final sentencing decision in isolation, the existing empirical literature has overlooked the role of prosecutors, whose decisions substantially shape sentences. Prosecutors enjoy very broad discretion to choose charges and to negotiate plea agreements, which often include stipulations of the facts on which sentences and presumptive sentences are based.

Charges carrying statutory mandatory minimum sentences are prosecutors' most powerful tool to constrain sentences, and disparities in the use of that tool can translate powerfully into sentence disparities. The 
importance of mandatory minimum charges in explaining sentence disparities is particularly striking because the crimes covered by this analysis have a relatively low prevalence of such charges (we identify such charges for 7.5 percent and 16.5 percent of white and black arrestees, respectively). For many offenses, mandatory minimums are simply not a prosecutorial option. Yet disparities in the initial charging of a minority of cases appear capable of explaining the majority of otherwiseunexplained black-white sentence disparities in the pool as a whole. Moreover, our estimates likely underestimate the role of mandatory minimums because of the use of highly conservative coding assumptions when charge data were ambiguous. Analyses using alternative data on mandatory minimums suggest that their use can explain virtually all of the otherwise unexplained sentencing disparity.

\section{Institutional Background and Existing Literature}

\section{A. Institutional Background}

In the federal system, approximately 97 percent of convictions are the product of guilty pleas. US federal prosecutors (like state prosecutors) possess enormous discretion. That discretion begins with the initial choice of what, if any, charges to bring. The federal criminal code is vast, and the definitions of crimes in the code often overlap, giving prosecutors a wide menu of charging options in a given case. Moreover, prosecutors must subjectively assess the strength of evidence and choose how to characterize ambiguous facts. For instance, if a gun is found in the car that transported a defendant to a burglary, the prosecutor must decide whether to allege that the burglary legally qualified as a "crime of violence" (18 U.S.C §16), that the gun qualified as a "firearm," and that the defendant "carried" it "during and in relation to" the burglary - all of which are necessary to trigger a 5-year mandatory minimum sentence under 18 U.S.C. $\$ 924(c)$, which would run consecutively to the burglary sentence. A lenient prosecutor might choose to "swallow the gun" and just charge burglary.

While initial charges can be amended as the prosecutor prepares the case or as a result of a plea agreement, the initial charges are still critical. The prosecutor enjoys essentially unilateral legal decision-making authority over initial charges, ${ }^{2}$ whereas subsequent plea deals must be agreed to by defendants (under counsel's advice). ${ }^{3}$ Moreover, the initial charge is usually the final charge, ${ }^{4}$ in part because Department of Justice

\footnotetext{
${ }^{2}$ Although felony indictments are issued by grand juries on prosecutorial request, this is a mere formality; prosecutors get the charges they seek in 99.9 percent of cases (Skolnik 1999).

${ }^{3}$ The initial charges are, of course, the first move in a strategic game and are therefore likely to be chosen taking into account expectations of judicial behavior and the defendant's bargaining position.

${ }^{4}$ The lead charge is identical at the initial and final stages in about 85 percent of cases in our sample.
} 
policy discourages subsequent "charge bargaining." Instead, plea bargaining often focuses on sentence recommendations and factual stipulations concerning aggravating and mitigating factors that will influence the sentence. The initial charges are the starting point for bargaining over all these terms. For this reason, the prosecutor's choice to bring particularly severe initial charges (such as those carrying mandatory minimums) can adversely affect outcomes for defendants even when the severe charges are reduced in plea bargaining; the threat of the initial charges may induce the defendant to plead guilty on less favorable terms.

Once a plea agreement is reached, the case is referred to the judge for sentencing. At that point a probation officer compiles a presentence investigation report on the defendant (which includes the defendant's full criminal history) for the judge to use in sentencing. ${ }^{6}$ Criminal statutes define extremely wide sentencing ranges for each crime. For example, the criminal code states that an individual convicted of computer fraud can receive a sentence ranging from 0 to 30 years in prison (the statutory range). From 1987 to 2005, judges were required to sentence defendants in accordance with the US Sentencing Guidelines. The guidelines are essentially a point system that specifies where a defendant should be placed within the wide statutory range. They thus limited judicial discretion to narrow sentencing ranges on the basis of factors mainly determined by plea agreements (the charges of conviction and the aggravating and mitigating "sentencing facts") along with the defendant's prior criminal history. Judges are not legally bound by the factual stipulations in plea agreements. However, most federal judges report that if the parties have agreed to a particular version of the facts, they typically defer to it, with the result that sentencing fact-finding, too, is to a large degree negotiated in the plea agreement (Gilbert and Johnson 1996; Schulhofer and Nagel 1997).

In 2005, the Supreme Court's Booker decision rendered the guidelines merely advisory, potentially weakening prosecutors' sentencing influence. But judges must still consult the guidelines, ${ }^{7}$ and Booker did not affect the binding nature of sentencing statutes. Some criminal statutes specify "mandatory minimum" sentences (which are often quite high), and even after Booker, prosecutors can tie judges' hands by bringing such

\footnotetext{
${ }^{5}$ In 2003, Attorney General John Ashcroft issued a memo ordering prosecutors to get special approval for charge reductions (Ashcroft 2003). The Ashcroft memo also ordered that the initial charge be the "most serious" offense that is "readily provable"; if obeyed, this would have essentially eliminated charging discretion. But this part of the policy contained no special supervision requirements and may have been unenforceable in practice (Miller 2004; Stith 2008); it was modified in 2010.

${ }^{6}$ The criminal history used in this analysis comes from this report. While federal prosecutors may often have a general knowledge of the defendant's criminal record well before sentencing, a full criminal history is not officially compiled and added to the file until sentencing.

${ }^{7}$ See 18 U.S.C. \$3553. The guidelines thus remain a key reference point (Scott 2010; Bushway, Owens, and Piehl [2012] find that state advisory guidelines influence sentences).
} 
charges. Parole was abolished in the federal system in 1987. Without a successful appeal (which is rare), the sentence conferred by the judge is the sentence served, subject to small, automatic reductions for good behavior in prison. ${ }^{8}$

\section{B. Existing Literature}

Legal scholars, judges, and practitioners broadly agree that prosecutorial decisions play a dominant role in determining sentences (see, e.g., Gilbert and Johnson 1996; Miller 2004; Stith 2008). In spite of this, prior empirical studies of racial and other demographic disparities in sentencing have considered judicial sentencing decisions only in isolation from the prosecutorial choices that preceded them. For instance, federal sentencing studies typically rely on Sentencing Commission (USSC) data alone and estimate disparities in the final sentence conditional on the "presumptive sentence," usually defined as the bottom of the guidelines range, as well as the statutory mandatory minimum. Estimates using this approach vary, but most find disparities favoring whites (see Mustard [2001] for a review of the earlier literature and Ulmer, Light, and Kramer [2011], US Sentencing Commission [2012], and Nowacki [2013] for some recent examples). Fischman and Schanzenbach (2012) use the "base offense level" under the guidelines to proxy for criminal conduct and also find substantial disparities favoring whites. ${ }^{9}$

Estimates of sentence disparity that condition on the presumptive guidelines sentence produce, in effect, a measure of racial disparity in judges' formal adherence to the guidelines. This is not, however, equivalent to estimating the disparity introduced by judges at sentencing because the judicial sentencing process also includes the fact-finding that helps to determine the guidelines range. The guidelines range is itself the product of decision making by the parties, including initial charging as well as plea bargaining over charges and stipulations of "sentencing facts." All of this decision making is carried out in anticipation of its sentencing consequences and is potentially subject to racial disparities. Policy makers as well as defendants themselves are likely interested not just in disparities in guidelines adherence but in the disparity in outcomes among offenders with the same underlying conduct and criminal history. If that is the quantity of interest, estimates that condition on the presumptive sentence (or variants of it) are likely to be biased.

\footnotetext{
${ }^{8}$ Federal prisoners who do not commit other crimes or major disciplinary infractions while in prison automatically receive "good time" credits. Individuals sentenced to more than 1 year in prison earn 54 days of good time for every 365 days in prison, such that they serve only 87 percent of their sentences (18 U.S.C. $\$ 3624$ ).

${ }^{9}$ The base offense level is determined prior to part of the Sentencing Guidelines factfinding process, but it is still determined by the crime of conviction and some initial findings of fact by the judge.
} 
The limited existing literature on racial disparity in prosecutorial decision making does not estimate its sentencing consequences. There are almost no studies of racial disparities in initial charge severity. One exception is the study by Miethe (1987), who found significant disparities favoring whites in a small sample of Minnesota cases. The few studies of disparities in plea bargaining generally find that prosecutors favor white defendants (see Shermer and Johnson [2010] for a review), but these studies are generally limited to deviations from the initial charges the prosecutor chose, treating the initial charge as exogenous. Finally, black defendants receive statutory "mandatory minimum" sentences more frequently than whites do, suggesting that these charges may be an important mechanism for sentencing disparities (US Sentencing Commission 2011; Fischman and Schanzenbach 2012). However, the existing studies that document this disparity do not answer the crucial question of why blacks more frequently face mandatory minimum sentences: differences in underlying crime patterns and criminal histories, or disparate exercise of prosecutorial charging discretion? Doing so requires charge and arrest data, which prior sentencing researchers have not had.

Prosecutors do not simply always seek to maximize a defendant's potential sentence. Prosecutorial discretion is essentially the power to be lenient, and prosecutors might choose to be lenient for a variety of reasons. Incentives shaping prosecutorial choices include pressure to maximize convictions or sentences, career concerns, resource constraints, and the desire to reduce workload and risk by encouraging guilty pleas (e.g., Landes 1971; Easterbrook 1983; Kessler and Piehl 1998; Glaeser, Kessler, and Piehl 2000; Baker and Mezzetti 2001). Prosecutors may be motivated by sympathy or a sense of fairness. Schulhofer and Nagel (1997) reviewed federal prosecutors' case files and found that they often manipulated charges to avoid sentencing consequences that were perceived as excessively harsh. Similarly, Bjerk (2005) finds evidence that state prosecutors manipulate charges to avoid triggering three-strikes laws. Selective leniency or empathy is one possible mechanism behind racial disparity in sentences. Linder (1996), Goette, Huffman, and Meier (2006), and Fong and Luttmer (2009) provide evidence of own-group bias or empathy in settings ranging from charitable giving to jury service.

\section{Data}

\section{A. Sample}

This study uses dyadic linking files provided by the Bureau of Justice Statistics to merge data from the US Marshals' Service (USMS), the Executive Office of the US Attorneys (EOUSA), the Administrative Office of the US 
Courts (AOUSC), and the US Sentencing Commission. The sample consists of male US citizens who were arrested and had cases referred to prosecutors from fiscal year 2006 through fiscal year $2008 .{ }^{10}$ The time period was chosen to ensure that all cases were processed entirely after the 2005 Booker decision but early enough to allow sufficient time for virtually all of them to have been resolved before the end of fiscal year 2009, the last year of available data. ${ }^{11}$ Since Booker gave judges the most sentencing discretion they had in decades, these years likely involve less prosecutorial influence over sentencing than earlier years.

The principal sample consists of property and fraud crimes, weapons offenses, regulatory offenses, and violent crimes (table 1). Immigration cases and other cases involving noncitizens were excluded because the stakes in those cases center on deportation, making them not directly comparable to other crimes. We also excluded traffic and liquor offenses, which are typically disposed of as "petty offenses": minor infractions that are not subject to the Sentencing Guidelines and are usually dealt with via citations that carry fines. ${ }^{12}$ Limitations in the arrest offense and initial charge data necessitated the exclusion of drug and child pornography cases from the main analysis, although they are included in supplementary analyses. ${ }^{13}$ The sample is further restricted to cases from the 50 US states and the District of Columbia. Further details are provided in the online data appendix. ${ }^{14}$

After these exclusions, the sample consists of 36,659 individuals who were arrested and referred to the US Attorney's Offices for possible prosecution in fiscal years 2006-8 (inclusive). Figure 2 shows the dispositions of these cases. Prosecutors chose not to file any charges in 790 cases (2 percent). In 2,647 cases ( 7 percent), prosecutors filed charges, but the

${ }^{10}$ For convenience, we refer to members of the sample as "arrestees" and the offense information as the "arrest offense." However, the sample also includes those who surrendered to avoid arrest, and the same data are available for these individuals. The analysis is limited to men because both racial disparity and criminal offense patterns differ substantially by gender (Starr 2012). Over 80 percent of federal defendants were male during this period.

${ }^{11}$ We estimate that fewer than 0.5 percent of cases initiated within this period were still pending at the end of 2009 (see the online data appendix).

${ }^{12}$ Such offenses would normally be routine state or local infractions but for their occurrence on federal land. Traffic and liquor offenses are usually merely tickets (Warner 2004), and those that are paid by mail do not appear at all in the federal data sets that we use; thus, only a highly selected sample of these infractions appear in the federal data.

${ }^{13}$ Drug quantity, a critical fact for offense severity, is not recorded in the initial charge data. Similarly, the child pornography charge data do not distinguish "receipt" from "possession"; only the former carries a high mandatory minimum sentence.

${ }_{14}$ The data appendix details additional exclusions intended to eliminate files opened and then immediately closed because of administrative errors, records that would otherwise have been double counted in the sample (because when records are transferred between districts, two records are created on the same case), and defendants who died before completion of the case. It also describes exclusions of cases in which the outcomes could not be determined, primarily because they were transferred to other prosecuting authorities, as well as analyses we conducted to ensure that results are robust to alternative treatments of these cases. 
TABLE 1

Summary Statistics for Main Sample

\begin{tabular}{|c|c|c|c|c|c|}
\hline & \multicolumn{2}{|c|}{ BLACK } & \multicolumn{2}{|c|}{ White } & \multirow[b]{2}{*}{$\begin{array}{l}\text { PERCENT } \\
\text { RECORDED }\end{array}$} \\
\hline & Mean & $\begin{array}{l}\text { Standard } \\
\text { Deviation }\end{array}$ & Mean & $\begin{array}{l}\text { Standard } \\
\text { Deviation }\end{array}$ & \\
\hline \multicolumn{6}{|l|}{ Defendant characteristics: } \\
\hline Age (years) & 32.317 & 10.145 & 38.63 & 12.850 & 100 \\
\hline \multicolumn{6}{|l|}{ Criminal history: } \\
\hline Category 1 & 20.43 & 40.31 & 44.97 & 49.75 & 89 \\
\hline Category 2 & 9.00 & 28.62 & 9.61 & 29.47 & 89 \\
\hline Category 3 & 17.34 & 37.86 & 13.15 & 33.79 & 89 \\
\hline Category 4 & 16.63 & 37.24 & 9.34 & 29.10 & 89 \\
\hline Category 5 & 11.41 & 31.80 & 6.95 & 25.43 & 89 \\
\hline Category 6 & 25.18 & 43.41 & 15.98 & 36.64 & 89 \\
\hline \multicolumn{6}{|l|}{ Education: } \\
\hline High school dropout & 42.99 & 49.5 & 29.16 & 45.5 & 87 \\
\hline High school graduate & 17.76 & 38.2 & 21.38 & 41.0 & 87 \\
\hline GED/vocational certificate & 20.1 & 40.1 & 20.62 & 40.5 & 87 \\
\hline At least some college & 19.15 & 39.3 & 28.84 & 45.3 & 87 \\
\hline Appointed counsel & 84.46 & 36.23 & 60.27 & 48.94 & 38 \\
\hline County poverty rate & 14.87 & 5.4 & 13.89 & 5.72 & 93 \\
\hline County income $(\$)$ & 21,011 & 4,619 & 20,488 & 5,115 & 93 \\
\hline County violent crime rate & .007 & .004 & .005 & .003 & 93 \\
\hline \multicolumn{6}{|l|}{ Case characteristics: } \\
\hline Multiple defendants & 25.4 & 43.5 & 27.3 & 44.6 & 100 \\
\hline \multicolumn{6}{|l|}{ Offense type: } \\
\hline Violent offenses & 13.01 & 33.64 & 11.19 & 31.52 & 100 \\
\hline Property offenses & 25.67 & 43.68 & 39.8 & 48.95 & 100 \\
\hline Regulatory offenses & 5.75 & 23.29 & 14.62 & 35.33 & 100 \\
\hline Weapons offenses & 55.57 & 49.69 & 34.4 & 47.5 & 100 \\
\hline $\begin{array}{l}\text { Any aggravating factors in } \\
\text { arrest notes }\end{array}$ & 59.65 & 49.06 & 43.15 & 49.53 & 49 \\
\hline \multicolumn{6}{|l|}{ Charge characteristics: } \\
\hline Any charges filed & 97.8 & 14.8 & 97.9 & 14.3 & 100 \\
\hline Mandatory minimum & & & & & \\
\hline charges filed & 16.4 & 37.0 & 7.5 & 26.4 & 100 \\
\hline \multicolumn{6}{|l|}{ Case resolution: } \\
\hline Any conviction & 90.7 & 29.1 & 90.6 & 29.2 & 100 \\
\hline Nonpetty conviction & 90.25 & 29.67 & 89.56 & 30.58 & 100 \\
\hline Sentenced for an offense with & & & & & \\
\hline a mandatory minimum & 21.3 & 40.9 & 9.54 & 29.4 & 100 \\
\hline Any incarceration & 79.7 & 40.2 & 67.7 & 46.8 & 100 \\
\hline Sentence length (months) & 64.89 & 81.71 & 38.09 & 60.76 & 100 \\
\hline Observations & 16,143 & & 20,516 & & \\
\hline
\end{tabular}

NoтE.-Unless specifically noted otherwise, the means are the percentage of arrestees with the listed characteristics. The difference in black and white means is significant at the 1 percent level for all variables except the percentage of arrestees with criminal history category $2(p=.06)$, a GED $(p=.26)$, any charges filed $(p=.38)$, any conviction $(p=.68)$, and any nonpetty conviction $(p=.03)$. Percent recorded is the percentage of arrestees for which that variable is available (nonmissing) in the data. 


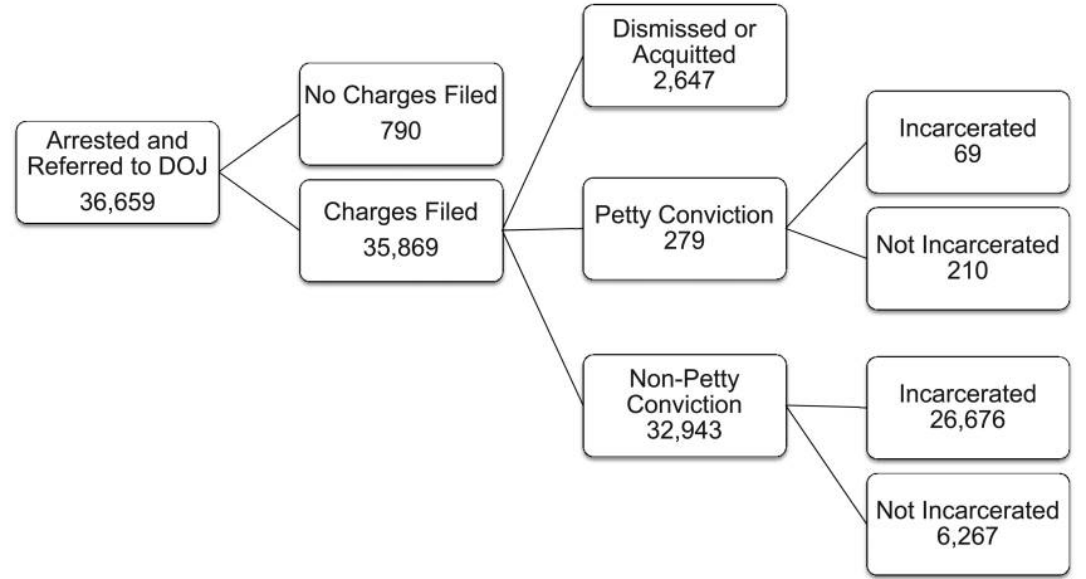

FIG. 2.-Disposition of federal arrests

case ended either in acquittal or with a complete dismissal of the charges. Less than 1 percent of the cases were disposed of as petty offenses. Approximately 90 percent of arrests in the sample resulted in convictions for nonpetty offenses, and four-fifths of these convictions resulted in incarceration. ${ }^{15}$ The average sentence length among those incarcerated was 64 months, and the average sentence faced by all arrestees was 50 months.

\section{B. Case and Defendant Characteristics}

The USMS data and the EOUSA data from the prosecutor's investigation file are available for all sample members. The district of arrest, arrest offense, and key demographic information (defendant's age, marital status, race, gender, and citizenship) are all drawn from the USMS data. The USMS records five race categories: white, black, Asian, Native American, and other/unknown; the last three groups, which collectively constitute approximately 5 percent of arrestees, are too small to analyze separately and are excluded. Hispanic ethnicity is not a category in the USMS data. Hispanics are therefore included in the white and black groups. ${ }^{16}$

\footnotetext{
${ }^{15}$ Our sample includes 26,676 nonpetty convictions resulting in incarceration and 6,267 nonpetty convictions resulting in alternative sentences such as probation or fines.

${ }^{16}$ Hispanic ethnicity is recorded by the USSC and is included in alternative analyses below but is excluded from the main analysis because it is not available for all defendants. In the subsample of cases recorded by the USSC, approximately 16 percent of defendants listed as white by the USMS data are identified as Hispanic in the USSC data. Only 1 percent of defendants classified as black in the USMS data are identified as Hispanic by the USSC.
} 
The USMS uses over 400 arrest offense codes to categorize the offenses recorded by the arresting officers. We condensed these into 134 groups, combining codes used in very few cases with similar codes that describe the same legal offense. The arrest offense represents the closest proxy available for the defendant's actual underlying criminal conduct, albeit an imperfect one, as discussed further below. The arrest offense is also a proxy for the information about the alleged criminal conduct that is available to the prosecutor at the time of charging. For arrests that occurred in fiscal years 2006 and 2007, it is possible to supplement the arrest offense with information from a text field with a written offense description recorded by the USMS on the basis of the arresting officer's notes. In addition, all analyses include an indicator for whether the investigation targeted multiple people, constructed on the basis of prosecutors' investigation files. Multiperson cases often involve alleged conspiracies with more serious charges.

The offender's education and criminal history category (as categorized under the Sentencing Guidelines) were also included in the main analyses. These variables come from the USSC's data and are available only for those sentenced for nonpetty offenses. ${ }^{17}$ It was therefore necessary to impute the criminal history and education for the 3,716 arrestees for whom this information was not available (approximately 10 percent of the sample). ${ }^{18}$ Our preferred imputation method is the "hot deck" approach commonly used in government surveys such as the Current Population Survey (Andridge and Little 2010). Each individual with missing education and criminal history is assigned the education and criminal history values from another sample member who perfectly matches him on race, arrest offense, 5-year age groups, and marital status. Nearly every individual had at least one exact match, ${ }^{19}$ and the median arrestee with unobserved criminal history had 151 exact matches. In cases with more than one exact match (99 percent of the observations), we employ a random hot deck method (Andridge and Little 2010). A single donor individual is selected at random from among the arrestee's exact matches and his education and criminal history values are used. This procedure was repeated 15 times with different random draws. Across all the analyses described below, the "black" coefficient was invariant to the individual selected at random from among the matches: the estimates across imputations differed only in the third or fourth decimal place. We report

\footnotetext{
${ }^{17}$ This includes everyone who is found guilty or pleads guilty to an offense covered by the guidelines, including those who are not sentenced to any incarceration.

${ }^{18}$ Criminal history and education were not available for the 790 individuals who were arrested but never charged with a crime, the 735 defendants charged only with petty offenses, and the 2,191 who were charged but not convicted of nonpetty offenses (these are individuals who either were acquitted or had their cases dropped or dismissed).

19 The 99 individuals for whom no matching individual could be found were excluded. These were predominantly individuals who were arrested for extremely rare offenses.
} 
the coefficients and their associated standard errors from the hot deck draw that produces the median black point estimate among the 15 hot deck draws.

Additional measures of the defendants' socioeconomic status are available for subsamples of defendants and are employed in supplementary analyses. The court records the county for all arrestees against whom charges are filed. County-level economic variables (per capita income, unemployment rate, and poverty rate) along with the violent crime rate per 1,000 county residents were constructed by linking AOUSC county fields to data from the 2000 census and from the 2007-9 Federal Bureau of Investigation's Uniform Crime Reports. The court also records the defendant's counsel type. This is a strong proxy for poverty because the government provides counsel only for indigent defendants. Counsel type is not recorded in 62 percent of cases, however, and is therefore excluded from the primary analysis.

Sentence length, the primary outcome of interest, comes from the USSC data. For individuals not included in the USSC data (primarily those in petty offense cases), we relied on the sentencing information from the prosecutor (EOUSA) and court files (AOUSC). The 9 percent of individuals who did not receive a sentence at all because they were never charged or not convicted were assigned an incarceration length of zero, as were the 18 percent of cases in which the defendant was convicted but not sentenced to any incarceration.

As discussed above, prosecutors' decisions are a potentially overlooked factor in black-white sentence disparities. In order to determine whether prosecutorial charging is capable of explaining the otherwiseunexplained disparities, we constructed measures of the severity of initial and final charges. AOUSC records up to five charges at the filing stage and five at the termination stage. However, the AOUSC data do not reliably code the severity of these charges beyond the felony-misdemeanor distinction. ${ }^{20}$ Instead, they record the section of the criminal code a defendant is charged with violating (e.g., 18 U.S.C. $\$ 924[c]$ ). We therefore develop and apply our own severity measures to translate the initial charges and their combinations into a defendant's sentencing exposure. These measures are based on detailed legal research into the sentencing law governing every federal crime and combination of crimes charged during the study period.

Our principal measures - the statutory maximum sentence and an indicator for whether a statutory mandatory minimum sentence is associated with the defendant's initial charges - have several theoretical ad-

\footnotetext{
${ }^{20}$ The AOUSC does list a "severity code" that is purportedly based on the statutory maximum, but it is often misleading, as explained further in the data appendix.
} 
vantages. After Booker, the statute provides the only firm legal constraints on sentencing. The statutory maximum and any mandatory minimums define the defendant's sentencing exposure. The statutory maximum associated with the initial charges is effectively the worst possible outcome potentially faced by the defendant going into plea bargaining. A limitation of the statutory maximum is that statutory ranges are often extremely wide, and the maximum is typically a large overestimate of the ultimate sentence. As for the statutory minimum, most criminal statutes set out sentencing ranges that start at zero; that is, there is no mandatory minimum period of incarceration. But when a charge carrying a "mandatory minimum" is brought, it can powerfully affect the sentence. After Booker, mandatory minimums are the prosecutor's only way to bind the judge to a higher sentence.

The construction of these measures is limited by the precision of the AOUSC's recorded charges, which sometimes encompass multiple subprovisions with different expected sentences. Whenever there were ambiguities concerning the presence of a mandatory minimum, we assumed that there was none, a very conservative assumption that led us to underestimate the ability of prosecutorial decisions to explain sentencing disparities. ${ }^{21}$ The AOUSC data are the only available source of information about the mandatory minimum associated with the initial charges. However, the sentencing judge records whether the final conviction is under a statute triggering a mandatory minimum sentence. This field is recorded in the USSC data and is not subject to ambiguity. In addition, while the initial charge data from AOUSC are ambiguous in drug and child pornography cases, the USSC reliably records whether a mandatory minimum was applicable to the final charges for those cases.

Summary statistics by race for all the variables described above are provided in table 1 . There is no racial difference in the raw probability of conviction (approximately 91 percent of black and white arrestees are ultimately convicted), but black defendants are more likely to be incarcerated and face longer sentences when incarcerated. Nearly 80 percent of black arrestees are incarcerated, compared with only 68 percent of white arrestees, and black arrestees' sentences are, on average, over 2 years (70 percent) longer. However, these differences may not be solely the result of race. The black and white defendant pools differ on two key legally relevant dimensions. First, black defendants, on average, have more extensive criminal histories: only 20 percent of black defendants are in the lowest criminal history category compared with 45 percent of white

${ }^{21}$ Mandatory minimums are often triggered by facts that the AOUSC charge data do not capture. Further details on the construction of the charge severity measures, including the way we employed legal research and the assumptions we made to resolve these ambiguities, are contained in the data appendix. 
defendants. Second, there are differences in the distribution of arrest offenses. Table 1 contains the distribution of arrestees across broad offense categories. For example, black defendants are more likely than white defendants to be arrested for weapons offenses. Black arrestees are also more likely to have at least one aggravating factor noted in the written description of the arrest offense. In addition, there are differences in observables that, while not legally relevant, could be correlated with case outcomes, in particular, socioeconomic status. Black arrestees are more likely to be sufficiently poor to qualify for a publicly funded attorney (84 percent compared with 60 percent), and 43 percent of black arrestees are high school dropouts compared with only 29 percent of whites. These differences in defendant and case characteristics could explain at least part of the observed disparities in sentences and incarceration.

\section{Estimation and Results}

\section{A. Charging and Disposition of Cases}

We begin by estimating racial disparities in how cases are treated in and progress through the criminal justice process. The decision points include the types of charges faced, conviction, and incarceration. These case outcomes are of interest in their own rights and could contribute to sentencing disparity. In particular, these analyses examine potential disparities in the treatment of less serious offenses, those in which there is a question of whether the defendant will be incarcerated at all.

Accordingly, we estimate logistic regressions of the form

$$
\operatorname{Pr}(Y=1 \mid \text { black, } X)=\frac{e^{(\alpha+\beta \text { black }+X \gamma)}}{1+e^{(\alpha+\beta \text { black }+X \gamma)}},
$$

in which $Y$ is the binary outcome of interest, black is a dummy for whether the defendant is black, and $X$ is a vector of additional offender and case characteristics that are already determined at or before the time of arrest: arrest offense, the defendant's age, criminal history, education, and an indicator for whether the investigation targeted multiple persons (hereinafter the "multidefendant flag"). The vector $X$ also includes federal district dummies to control for any differences in policy or decision making, and standard errors are clustered by federal district in order to account for possible correlated shocks. ${ }^{22}$

Table 2 contains the resulting odds-ratio estimates for the full sample of arrestees. Black arrestees are slightly less likely to face any federal charges: the average probability of charges for white arrestees is 97.9 per-

\footnotetext{
${ }^{22}$ The federal judicial districts are the unit of organization for the judiciary, the prosecutor's offices, and the public defender's offices.
} 
TABLE 2

Odds of Charging, Conviction, and Incarceration

\begin{tabular}{|c|c|c|c|c|c|c|}
\hline & $\begin{array}{c}\text { Any } \\
\text { Charge } \\
(1)\end{array}$ & $\begin{array}{c}\text { Mandatory } \\
\text { Minimum } \\
\text { Charge } \\
(2)\end{array}$ & $\begin{array}{c}\text { Any } \\
\text { Conviction } \\
(3)\end{array}$ & $\begin{array}{c}\text { Nonpetty } \\
\text { Conviction } \\
(4)\end{array}$ & $\begin{array}{c}\text { Mandatory } \\
\text { Minimum } \\
\text { Conviction } \\
\text { (5) }\end{array}$ & $\begin{array}{c}\text { Any } \\
\text { Incarceration } \\
\text { (6) }\end{array}$ \\
\hline Black & $\begin{array}{c}.838^{+} \\
{[.084]}\end{array}$ & $\begin{array}{l}1.752 * * \\
{[.120]}\end{array}$ & $\begin{array}{l}.896^{+} \\
{[.057]}\end{array}$ & $\begin{array}{l}.926 \\
{[.055}\end{array}$ & $\begin{array}{l}1.724 * * \\
{[.118}\end{array}$ & $\begin{array}{l}1.003 \\
{[.040]}\end{array}$ \\
\hline Age & $\begin{array}{l}.993^{*} \\
{[.003]}\end{array}$ & $\begin{array}{l}.973^{* *} \\
{[.002]}\end{array}$ & $\begin{array}{l}.987^{* * *} \\
{[.002]}\end{array}$ & $\begin{array}{l}.988^{* * *} \\
{[.002]}\end{array}$ & $\begin{array}{l}.971^{* *} \\
{[.003]}\end{array}$ & $\begin{array}{l}.989^{* *} \\
{[.001]}\end{array}$ \\
\hline $\begin{array}{l}\text { Multiple } \\
\text { defendants }\end{array}$ & $\begin{array}{l}.653 * * \\
{[.065]}\end{array}$ & $\begin{array}{l}1.805^{* *} \\
{[.108]}\end{array}$ & $\begin{array}{l}.787 * * \\
{[.051]}\end{array}$ & $\begin{array}{l}.804 * * \\
{[.051]}\end{array}$ & $\begin{array}{l}1.64 * * \\
{[.104]}\end{array}$ & $\begin{array}{l}1.009 \\
{[.041]}\end{array}$ \\
\hline $\begin{array}{l}\text { Criminal } \\
\text { history } 2\end{array}$ & $\begin{array}{l}1.108 \\
{[.149]}\end{array}$ & $\begin{array}{l}1.375^{* *} \\
{[.112]}\end{array}$ & $\begin{array}{l}1.104 \\
{[.077]}\end{array}$ & $\begin{array}{c}.921 \\
{[.072]}\end{array}$ & $\begin{array}{l}1.327 * * \\
{[.124]}\end{array}$ & $\begin{array}{l}1.871 * * \\
{[.082]}\end{array}$ \\
\hline $\begin{array}{l}\text { Criminal } \\
\text { history } 3\end{array}$ & $\begin{array}{l}.969 \\
{[.153]}\end{array}$ & $\begin{array}{l}1.185 \\
{[.105]}\end{array}$ & $\begin{array}{c}.974 \\
{[.063]}\end{array}$ & $\begin{array}{l}.960 \\
{[.055]}\end{array}$ & $\begin{array}{l}1.170 \\
{[.114]}\end{array}$ & $\begin{array}{l}2.511 * * \\
{[.119]}\end{array}$ \\
\hline $\begin{array}{l}\text { Criminal } \\
\text { history } 4\end{array}$ & $\begin{array}{c}.916 \\
{[.144]}\end{array}$ & $\begin{array}{l}1.028 \\
{[.104]}\end{array}$ & $\begin{array}{c}.957 \\
{[.071]}\end{array}$ & $\begin{array}{c}.918 \\
{[.070]}\end{array}$ & $\begin{array}{l}1.055 \\
{[.114]}\end{array}$ & $\begin{array}{l}3.671 * * \\
{[.185]}\end{array}$ \\
\hline $\begin{array}{l}\text { Criminal } \\
\text { history } 5\end{array}$ & $\begin{array}{l}1.003 \\
{[.178]}\end{array}$ & $\begin{array}{l}1.125 \\
{[.124]}\end{array}$ & $\begin{array}{c}.932 \\
{[.082]}\end{array}$ & $\begin{array}{c}.947 \\
{[.077]}\end{array}$ & $\begin{array}{l}1.052 \\
{[.121]}\end{array}$ & $\begin{array}{l}4.331^{* *} \\
{[.327]}\end{array}$ \\
\hline $\begin{array}{l}\text { Criminal } \\
\text { history } 6\end{array}$ & $\begin{array}{c}.862 \\
{[.129]}\end{array}$ & $\begin{array}{l}1.351^{*} \\
{[.141]}\end{array}$ & $\begin{array}{c}.976 \\
{[.083]}\end{array}$ & $\begin{array}{l}.905 \\
{[.074]}\end{array}$ & $\begin{array}{l}1.231 \\
{[.146]}\end{array}$ & $\begin{array}{l}4.894 * * \\
{[.373]}\end{array}$ \\
\hline $\begin{array}{l}\text { High school } \\
\text { graduate }\end{array}$ & $\begin{array}{c}.917 \\
{[.110]}\end{array}$ & $\begin{array}{l}1.010 \\
{[.054]}\end{array}$ & $\begin{array}{c}.962 \\
{[.064]}\end{array}$ & $\begin{array}{l}.948 \\
{[.055]}\end{array}$ & $\begin{array}{c}.992 \\
{[.060]}\end{array}$ & $\begin{array}{l}.832 * * \\
{[.032]}\end{array}$ \\
\hline $\begin{array}{l}\text { GED/ } \\
\text { vocational }\end{array}$ & $\begin{array}{c}.971 \\
{[.100]}\end{array}$ & $\begin{array}{l}1.008 \\
{[.057]}\end{array}$ & $\begin{array}{c}.978 \\
{[.064]}\end{array}$ & $\begin{array}{c}.952 \\
{[.059]}\end{array}$ & $\begin{array}{l}.951 \\
{[.077]}\end{array}$ & $\begin{array}{c}.928 \\
{[.041]}\end{array}$ \\
\hline $\begin{array}{l}\text { At least some } \\
\text { college }\end{array}$ & $\begin{array}{c}.938 \\
{[.099]} \\
\end{array}$ & $\begin{array}{l}.973 \\
{[.062]}\end{array}$ & $\begin{array}{l}1.033 \\
{[.067]}\end{array}$ & $\begin{array}{c}.979 \\
{[.051]}\end{array}$ & $\begin{array}{c}.897 \\
{[.065]}\end{array}$ & $\begin{array}{l}.954 \\
{[.035]}\end{array}$ \\
\hline Observations & 34,804 & 35,320 & 36,482 & 36,601 & 34,872 & 36,659 \\
\hline
\end{tabular}

Note.-Odds ratios are from logistic regressions with standard errors block bootstrapped by district in brackets. The odds ratios reported are from the hot deck imputation of criminal history and education that produces the median black odds ratio across the 15 hot deck imputations of criminal history and education. All regressions also include dummy variables for the arrest offense and the federal district. Observations differ across outcomes because of the perfect prediction of the outcome by a handful of arrest offenses.

+ Significant at the 10 percent level.

* Significant at the 5 percent level.

** Significant at the 1 percent level.

cent, while the estimated probability for comparable black arrestees is 97.6 percent. ${ }^{23}$ However, there is a dramatic disparity disfavoring blacks in the likelihood of facing severe charges. All else equal, black arrestees are

${ }^{23}$ These estimates and the ones that follow in the main text are calculated using the odds ratios in table 2 and the base probabilities in table 1. Alternatively, calculating the average 
much more likely to initially face a charge carrying a mandatory minimum (7.5 percent for the average white arrestee compared to 12.4 percent for a comparable black arrestee; col. 2) and to be convicted of such charges ( 4.5 percent for white arrestees, 7.5 percent for comparable black arrestees; col. 5$).^{24}$

Turning to the overall probability of conviction, there is a slight and marginally significant disparity favoring black arrestees (90.6 percent for the average white arrestee vs. 89.6 percent for a comparable black arrestee; table 2 , col. 3). ${ }^{25}$ This disparity seems to be driven primarily by petty offense convictions; there is no significant disparity in the probability that an arrestee is convicted of a nonpetty offense (col. 4). Despite the sizable raw differences in incarceration rates, there is no unexplained racial disparity in the probability of incarceration after accounting for defendant and case characteristics (col. 6).

\section{B. Aggregate Disparities in the Distribution of Sentence Lengths}

We now turn to our principal focus: the estimation of racial disparity in sentence lengths. We estimate quantile regressions of the form

$$
Q_{\theta}[\ln (S)]=\alpha_{\theta}+\beta_{\theta} \text { black }+X \gamma
$$

where $S$ is the length of incarceration in months, black is an indicator for whether the defendant is black, and $\theta$ denotes the quantile of interest. The term $X$ is a set of additional defendant and case characteristics that varies across specifications as described below. The term $\beta_{\theta}$ is the coefficient of interest and is the marginal effect of race on the $\theta$ percentile of the sentence distribution. Standard errors are calculated by block bootstrapping each estimate by district 100 times. $^{26}$

Incarceration is the outcome of interest, and acquittals, dismissals, and purely monetary or probationary sentences all result in zero incarceration. We treat all the nonincarceration outcomes as the equivalent of

\footnotetext{
marginal effects (AME) of being black by averaging over the marginal effect of race on each individual arrestee's estimated probability of facing charges when evaluated at the true values of the other covariates for that individual produces nearly identical estimates (a 0.4 percentage point decrease in the probability of facing charges; standard error $[\mathrm{SE}] 0.2$, calculated using the delta method).

${ }^{24}$ Calculating the AME by averaging over the individual marginal effects (as in $\mathrm{fn.} 23$ ) produces nearly identical estimates. The AME of being black is then a 4.9 (SE 0.6) and 3.4 (SE 0.4) percentage point increase in the probability of facing mandatory minimum charges and being convicted of them, respectively.

${ }^{25}$ Averaging over the individual marginal effects (as in fn. 23) results in an AME of 0.9 (SE 0.5).

${ }^{26}$ Iterations of up to 200 bootstrap loops produced point estimates and standard errors that were equivalent to the fourth decimal place.
} 
1-month sentences. ${ }^{27}$ An advantage of the quantile regression approach is that the estimates of the conditional quantiles substantially above the affected portion of the distribution are robust to this valuation decision (Bloomfield and Steiger 1983; Powell 1986; Johnson, Kitamura, and Neal 2000; Angrist, Bettinger, and Kremer 2006). After the imputation, 27.6 percent of arrestees have 1-month sentences, and we therefore begin our estimation at the fourth decile. ${ }^{28}$

Table 3 presents the quantile regression estimates. Row 1 contains the large raw racial disparities in incarceration length at each decile, with no covariates. Row 2 adds controls for the primary offense characteristics to the quantile regressions: the arrest offense and the multidefendant indicator. Row 3 adds the most important predetermined characteristic of the arrestee: criminal history, which, along with offense severity, is the primary factor that federal judges are directed by the Sentencing Guidelines to consider. Finally, row 4 adds other factors that, while not legally relevant, are potentially correlated with race and could influence the sentence: age, education, and judicial district. The resulting estimates of $\beta_{\theta}$ are the amount of racial disparity in sentences after conditioning on arrest offense and other precharge covariates, representing the aggregate unexplained disparity in sentences that appears to be introduced via the postarrest justice process.

The majority, but not all, of the raw disparity can be explained by the legally relevant variables. After the inclusion of the arrest offense and multidefendant flag, the unexplained black-white sentence disparity at the median is only 34 percent and ranges from 24 to 34 percent across the deciles (row 2). After the inclusion of criminal history, the conditional effect of race ranges from only 13 to 16 percent (row 3). Taken together, the legally relevant factors are capable of explaining most of the observed racial disparity in sentences. Following the inclusion of the additional demographic and geographic covariates (education, age, and judicial district), the estimated disparity falls further to 8-10 percent (row 4). The inclusion of the district is primarily responsible for this reduction. It appears that sentences for all defendants are more severe in the federal districts in which black arrestees are concentrated.

However, even after the inclusion of all the aforementioned factors, significant racial disparities favoring whites remain at every decile. In addition, after conditioning on the observed characteristics, race ap-

\footnotetext{
${ }^{27}$ Assigning some nonzero value to nonincarceration sentences was necessary to enable $\log$ transformation. In the ordinary least squares (OLS) regression shown in App. table A1, they are valued as zeroes instead and sentences are not log transformed. We also assign a value of 1 month to the 0.2 percent of prison sentences that were less than 1 month.

${ }^{28}$ The estimates are robust to alternative sentence values for those not ultimately sentenced to incarceration. For example, imputing a 0.1-month sentence to those with no incarceration slightly increases the estimated racial disparity at the fourth decile and has no noticeable effect above it.
} 
TABLE 3

Black-White Log Sentence Disparity

\begin{tabular}{lcccccc}
\hline \hline & Q40 & Q50 & Q60 & Q70 & Q80 & Q90 \\
\hline 1. No controls & $.993^{* *}$ & $.721^{* *}$ & $.711^{* *}$ & $.588^{* *}$ & $.588^{* *}$ & $.588^{* *}$ \\
& {$[.212]$} & {$[.0692]$} & {$[.0723]$} & {$[.0626]$} & {$[.0618]$} & {$[.0590]$} \\
2. Offense characteristics & $.312^{* *}$ & $.340^{* *}$ & $.280^{* *}$ & $.241^{* *}$ & $.256^{* *}$ & $.245^{* *}$ \\
& {$[.0556]$} & {$[.0493]$} & {$[.0403]$} & {$[.0359]$} & {$[.0350]$} & {$[.0524]$} \\
3. Offense and criminal history & $.127 * *$ & $.131^{* *}$ & $.151^{* *}$ & $.149^{* *}$ & $.16^{* *}$ & $.157^{* *}$ \\
& {$[.041]$} & {$[.030]$} & {$[.030]$} & {$[.032]$} & {$[.035]$} & {$[.032]$} \\
4. Full set of controls & $.096^{* * *}$ & $.087^{* *}$ & $.086^{* *}$ & $.081^{* *}$ & $.097^{* *}$ & $.101^{* *}$ \\
& {$[.025]$} & {$[.020]$} & {$[.017]$} & {$[.018]$} & {$[.022]$} & {$[.022]$} \\
\hline
\end{tabular}

Note. $-N=36,649$. Each cell contains the coefficient on black from a separate quantile regression. In rows 3 and 4, the point estimate is the median point estimate across the 15 hot deck imputations of criminal history and education. Row 2 includes arrest offense and multidefendant case indicators. Row 3 includes the controls in row 2 along with indicators for the defendant's criminal history (category 1 is the excluded category). Row 4 includes all of the controls from row 3 along with defendant age, education dummies, and dummies for the federal district. Standard errors block bootstrapped by district are in brackets.

+ Significant at the 10 percent level.

* Significant at the 5 percent level.

** Significant at the 1 percent level.

pears to simply be a locational shift parameter for the conditional sentence distribution. That is, the conditional effect of race is approximately 9 percent, and we fail to reject the hypothesis that the disparity is constant across the estimated deciles of the conditional distribution. If there is no heterogeneity in the parameter of interest, then the estimate at the conditional median is a consistent estimator of the conditional mean effect. In fact, one sees a similar pattern of disparity in OLS regressions of sentence length, although the estimated disparities are larger (table A1). The inclusion of arrest characteristics cuts the unconditional estimate of mean disparity in half. The inclusion of the full set of controls further reduces it to a quarter of the raw disparity. However, an unexplained gap of approximately 7 months remains. ${ }^{29}$

\section{Alternative Explanations}

The estimates presented above include an extremely rich set of controls. However, in the absence of experimental variation, it is still possible that the racial disparity we document is the result of an unobserved omitted factor that is correlated with race. Below we consider the leading potential alternative explanations for the racial disparity in sentences. Table 4 contains alternative specifications of the median regression, while figure 3 presents a graphical representation of the estimates at each of the deciles

\footnotetext{
${ }^{29}$ These estimates are from OLS regressions of sentences (measured in months) with the same covariates as the quantile regressions.
} 
TABLE 4

Black-White Log Sentence Disparity at the Median: Supplementary Analyses

\begin{tabular}{|c|c|c|c|c|}
\hline & \multicolumn{4}{|c|}{ Alternate Criminal History Imputations } \\
\hline & \multirow{2}{*}{$\begin{array}{l}\text { A. Main (Table 3, } \\
\text { Row 4) }\end{array}$} & \multirow{2}{*}{$\begin{array}{l}\text { B. Below Mean } \\
\text { for Arrest } \\
\text { Offense }\end{array}$} & \multicolumn{2}{|c|}{$\begin{array}{l}\text { C. Extreme Criminal } \\
\text { History Bounds }\end{array}$} \\
\hline & & & Lower & Upper \\
\hline \multirow[t]{2}{*}{ Black } & $.087 * *$ & $.082 * *$ & $.052 *$ & $.112 * *$ \\
\hline & {$[.020]$} & {$[.020]$} & {$[.023]$} & {$[.024]$} \\
\hline \multirow[t]{4}{*}{ Observations } & 36,659 & 36,659 & 36,659 & 36,659 \\
\hline & \multicolumn{4}{|c|}{ Additional Case and Arrestee Characteristics } \\
\hline & \multirow{2}{*}{$\begin{array}{l}\text { D. No Prearrest } \\
\text { Indictment }\end{array}$} & \multirow{2}{*}{$\begin{array}{l}\text { E. Original } \\
\text { Arrest } \\
\text { Codes }\end{array}$} & \multicolumn{2}{|c|}{ F. Police Notes } \\
\hline & & & Available & Included \\
\hline \multirow[t]{2}{*}{ Black } & $.088 * *$ & $.087 * *$ & $.058 *$ & $.061 * *$ \\
\hline & {$[.022]$} & {$[.020]$} & {$[.024]$} & {$[.023]$} \\
\hline \multirow[t]{3}{*}{ Observations } & 21,313 & 36,086 & 18,096 & 18,096 \\
\hline & G County & \multicolumn{2}{|c|}{ H. Counsel Type } & \\
\hline & Characteristics & Recorded & Included & \\
\hline \multirow[t]{2}{*}{ Black } & $.089 * *$ & $.137 * *$ & $.138 * *$ & \\
\hline & {$[.019]$} & {$[.030]$} & {$[.028]$} & \\
\hline \multirow[t]{3}{*}{ Observations } & 36,659 & 13,838 & 13,838 & \\
\hline & \multicolumn{2}{|c|}{ I. Hispanic } & I Include & \\
\hline & Recorded & Included & Noncitizens & \\
\hline \multirow[t]{2}{*}{ Black } & $.091 * *$ & $.105^{* *}$ & $.096 * *$ & \\
\hline & {$[.018]$} & {$[.017]$} & {$[.021]$} & \\
\hline Observations & 28,492 & 28,492 & 43,309 & \\
\hline
\end{tabular}

Note.-Each cell contains the black coefficient from a separate median regression. All regressions include all of the control variables from table 3, row 4. Each point estimate is the median point estimate across the 15 hot deck imputations of criminal history and education. Standard errors block bootstrapped by district are in brackets.

+ Significant at the 10 percent level.

* Significant at the 5 percent level.

** Significant at the 1 percent level.

beginning with the fourth for the same alternative specifications. For comparison purposes, table 4 , column A, and figure $3 a$ reproduce the main estimates from table 3 (row 4).

First, the hot deck imputation implicitly assumes that criminal history and education are missing at random within race by arrest offense by age group by marital status cells and thus have the same conditional distribution in the cases in which they are and are not observed. ${ }^{30}$ This is a strong

${ }^{30}$ Our preferred assumption is that criminal history is "missing at random" within cells. As a rough approximation, this assumption is reasonable. Over 90 percent of the arrestees with unobserved criminal histories are declinations, dismissals, and acquittals, any of which can 
assumption. Prosecutors have access to federal databases, and it is likely that they have at least some knowledge of arrestees' criminal histories prior to the official compilation of the presentencing report. This knowledge could influence their decisions. We observe criminal history and education only in cases that proceed to sentencing on a nonpetty offense, and it is possible that the likelihood of such sentencing could be affected by the arrestee's criminal history or education. To test the robustness of the estimates to relaxing the missing-at-random assumption, we replace it with the assumption that cases that do not proceed to sentencing on a nonpetty charge are, on average, less severe, conditional on the observables, than those that do. Hot deck imputation for unobserved criminal history and education within race, age, marital status, and arrest offense cells is still employed, but the matches are further constrained to cases that have below-average sentences for their arrest offense. This subset of cases may involve relatively less serious conduct and also has a substantially lower distribution of criminal histories. The resulting estimates of racial disparity are only slightly lower than those in the main specification (col. B of table 4; fig. 2b).

We next test if even more extreme assumptions about the unobserved criminal histories are capable of explaining the observed racial disparity in sentences. ${ }^{31}$ To that end, we reestimate the racial disparity in sentences under the two most extreme possible criminal history assumptions. First, we impute the maximum criminal history category (category 6) to all black defendants with missing criminal history and the minimum category (category 1) to all white defendants with missing criminal history. This is equivalent to an assumption that black defendants are less likely to face sentencing on a nonpetty offense conditional on their criminal history and will generate a lower bound on the estimates of the racial disparity. To generate an upper bound, we reverse the assumption and assign the minimum possible criminal history score to all black defendants with missing criminal histories and the maximum possible score for the white defendants with missing criminal histories. Under these extreme assumptions, the conditional effect of race at the median ranges from 5 to 11 percent (table 4, col. C; fig. 3c). The magnitude of the coefficients is affected, but the unexplained racial disparity remains economically and statistically significant. The assumptions that produced these bounds are unrealistic. The average racial difference in criminal histories observed in our data is only approximately one criminal history category. Thus, even

occur in either "more serious" or "less serious" cases because of weaknesses in the evidence. The alternative "less serious" assumption is probably more realistic for the 279 arrestees whose criminal history is unobserved because they were convicted of a petty offense.

${ }^{31}$ We focus on criminal history rather than education because education is not a substantial explanator of the race gap in sentences, and it is also less likely that prosecutors would know the defendant's education level before the presentence investigation report is issued. 

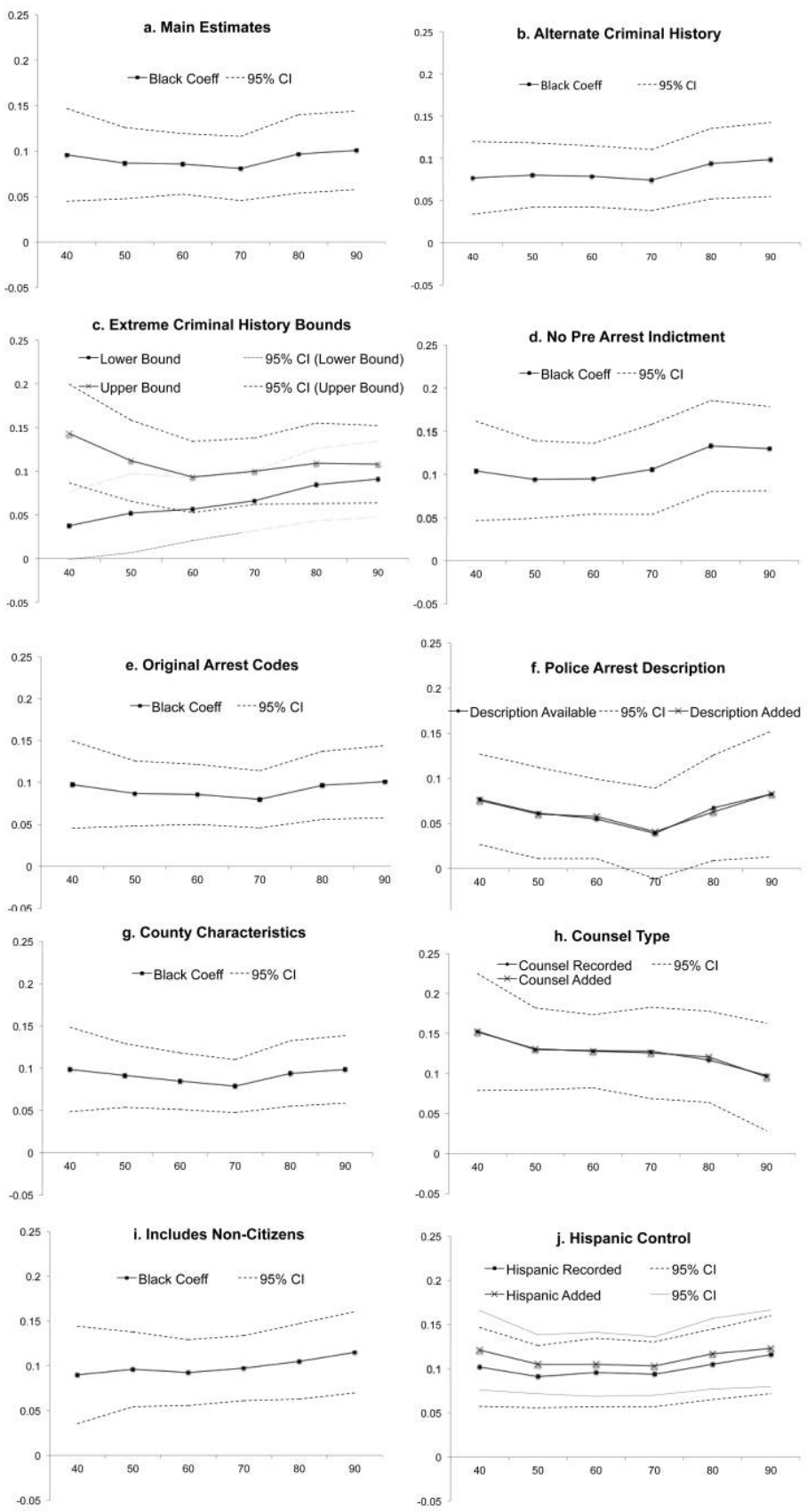

Fig. 3.- Impact of race on sentence length at each decile. Each point is the black coefficient at that decile from a separate quantile regression of log sentence length following the specification in row 4 of table 3 . 
the most extreme assumptions about unobserved differences in criminal history are incapable of explaining all the racial disparity in sentences.

We next consider other aspects of black defendants' cases that could explain their higher sentences-in particular, the possibility that differences in criminal conduct are not completely captured by the arrest offense. One concern is that in some cases the arrest offense may not be free from prosecutorial influence. However, the estimates are robust to excluding cases in which the indictment preceded the arrest (table 4, col. D; fig. 3d). These are the cases in which prosecutors are most likely to have played a substantial role in the investigation prior to the arrest and may have thus influenced the recording of the arrest offense. Next, while the arrest offense codes are fairly specific, there is still variance in severity within a given arrest offense. If black defendants committed more serious versions of the same arrest offenses, that could explain their higher sentences. Our main estimates group certain infrequently used arrest offense codes together with more common ones on the basis of legal similarity. The estimates are robust to the use of the original arrest codes (table 4, col. E; fig. 3e). We further tested the possibility of omitted nuances in the offenses by adding indicators for whether the additional written description of the arrest offense mentioned guns, other weapons, drugs, child victims, police victims, conspiracy, or racketeering in the arrest description-all of which are potential indicators of greater offense severity. The written description is available only for arrests prior to fiscal year 2008. ${ }^{32}$ Within the subsample for which the description is available, the addition of these indicators does not change the disparity estimates (compare the two estimates in table 4, col. F, and the corresponding graph in fig. $3 f$; the two solid lines are the estimates of the black coefficient at each decile for this subsample with and without the arrest description indicators included in the regression).

Race and socioeconomic status are highly correlated in the United States, raising the possibility that the apparent disparity in sentences results from socioeconomic status rather than from race. We do not directly observe the defendant's income, but the estimates are robust to the inclusion of the unemployment rate, poverty rate, and per capita income (as well as the crime rate) of the defendant's county (table 4, col. G; fig. $3 g$ ). The estimates are also robust to the inclusion of an indicator for whether the defendant was represented by publically appointed counsel ("counsel type"), a good proxy for poverty. Having publicly appointed counsel does not explain any of the racial disparity in sentencing at any decile within the subsample for which counsel type is recorded (table 4, col. H; fig. 3h).

${ }^{32}$ The base estimates are lower for this subsample. The written notes are available only for those arrested in fiscal year 2007 or earlier, and disparity appears to have grown over the 3-year period. 
The arrest data include race, but not ethnicity. Hispanics therefore cannot be separately identified in the arrest data but can be identified in the sentencing data. In the arrest data, 94 percent of those identified as Hispanic in sentencing data are classified as white. If Hispanics receive longer sentences than non-Hispanic whites, this could mean that our approach understates the amount of racial disparity in sentences between non-Hispanic white and black defendants. Controlling for Hispanic ethnicity results in a small but statistically insignificant increase in the estimated disparity at the median (from 9 to 10 percent) within the subsample of cases for which ethnicity is recorded (compare the estimates in table 4, col. I, and the lines in fig. $3 i$ ).

The main sample excludes non-US citizens. Noncitizens are predominantly white and Hispanic and may be more disadvantaged than white US citizen arrestees. The exclusion of a subset of white arrestees who might be expected to face worse outcomes could bias the estimated racial disparity upward. However, the estimated racial disparity in sentences is, if anything, slightly larger when noncitizens are added (table 4, col. J; fig. $3 j$ ). ${ }^{33}$

\section{Procedural Mechanisms: The Role of Prosecutorial Discretion}

The preceding analysis estimated racial disparity conditional on defendant and case characteristics when the arrestee entered the justice system. Next, we ask whether the exercise of prosecutorial discretion is capable of explaining the remaining black-white sentence disparity. We reestimate equation (2) adding controls for how the prosecutor chose to handle the case. Specifically, we include the statutory sentencing range of the initial charges chosen by the prosecutor: the statutory maximum sentence and an indicator for whether the charges carry a mandatory minimum sentence. We find that prosecutors' charging decisions, and particularly the mandatory minimum decision, are capable of explaining at least half of the otherwise unexplained racial disparity. Adding the statutory maximum of the initial charges along with an indicator for the presence of a charge carrying a mandatory minimum sentence reduces the coefficients on race by at least half (table 5, row 2). Further, it appears that this reduction is primarily coming from the presence of charges carrying mandatory minimum sentences. The estimates are similar when the statutory maximum is removed (row 3), suggesting that the mandatory minimum variable is the most important charging decision in terms of its effects on sentencing disparity. The statutory maximum does have some explanatory power when it is the only charging measure

\footnotetext{
33 The estimates are also robust to the addition of controls for marital status. In addition, the estimated disparities are not confined to any one region of the country (such as the South).
} 
TABLE 5

Black-White Log Sentence Disparity after Accounting for Charge Severity

\begin{tabular}{|c|c|c|c|c|c|c|}
\hline & Q40 & Q50 & Q60 & Q70 & Q80 & Q90 \\
\hline Main specification (table 3 , row 4 ) & $\begin{array}{l}.096 * * \\
{[.025]}\end{array}$ & $\begin{array}{l}.087 * * \\
{[.020]}\end{array}$ & $\begin{array}{l}.086^{* * *} \\
{[.017]}\end{array}$ & $\begin{array}{l}.081 * * \\
{[.018]}\end{array}$ & $\begin{array}{l}.097 * * \\
{[.022]}\end{array}$ & $\begin{array}{l}.101 * * \\
{[.022]}\end{array}$ \\
\hline $\begin{array}{l}\text { With statutory maximum of } \\
\text { charges and mandatory } \\
\text { minimum charge indicator }\end{array}$ & $\begin{array}{l}.053^{*} \\
{[.023]}\end{array}$ & $\begin{array}{l}.044^{*} \\
{[.019}\end{array}$ & $\begin{array}{l}.032 * \\
{[.016]}\end{array}$ & $\begin{array}{l}.027^{+} \\
{[.016]}\end{array}$ & $\begin{array}{l}.034^{*} \\
{[.016]}\end{array}$ & $\begin{array}{l}.049 * \\
{[.020]}\end{array}$ \\
\hline $\begin{array}{l}\text { With mandatory minimum } \\
\text { charge indicator }\end{array}$ & $\begin{array}{l}.045^{*} \\
{[.020]}\end{array}$ & $\begin{array}{l}.043^{*} \\
{[.021]}\end{array}$ & $\begin{array}{l}.03 \\
{[.019]}\end{array}$ & $\begin{array}{l}.025 \\
{[.016]}\end{array}$ & $\begin{array}{l}.035^{+} \\
{[.019]}\end{array}$ & $\begin{array}{l}.053 * \\
{[.021]}\end{array}$ \\
\hline $\begin{array}{l}\text { With mandatory minimum } \\
\text { conviction indicator }\end{array}$ & $\begin{array}{l}.057 * * \\
{[.022]}\end{array}$ & $\begin{array}{l}.053 * * \\
{[.019]}\end{array}$ & $\begin{array}{l}.039 * \\
{[.016]}\end{array}$ & $\begin{array}{l}.032^{*} \\
{[.015]}\end{array}$ & $\begin{array}{l}.040^{*} \\
{[.018]}\end{array}$ & $\begin{array}{l}.049 * * \\
{[.018]}\end{array}$ \\
\hline $\begin{array}{l}\text { With mandatory minimum } \\
\text { present at sentencing } \\
\text { indicator (USSC measure) }\end{array}$ & $\begin{array}{l}.036^{+} \\
{[.019]}\end{array}$ & $\begin{array}{c}.031 \\
{[.020]}\end{array}$ & $\begin{array}{l}.02 \\
{[.020]}\end{array}$ & $\begin{array}{l}.003 \\
{[.016]}\end{array}$ & $\begin{array}{c}.002 \\
{[.016]}\end{array}$ & $\begin{array}{r}-.008 \\
{[.017]}\end{array}$ \\
\hline
\end{tabular}

Note. $-N=36,659$. Each cell contains the coefficient on black from a separate quantile regression. Each point estimate is the median point estimate across the 15 hot deck imputations of criminal history and education. Standard errors block bootstrapped by district are in brackets.

+ Significant at the 10 percent level.

* Significant at the 5 percent level.

** Significant at the 1 percent level.

added, but not as much as the mandatory minimum, and it does not contribute additional explanatory power once the mandatory minimum is already included in the regression (rows 2 and 3). ${ }^{34}$

Thus, the prosecutor's decision to bring a mandatory minimum charge alone appears capable of explaining more than half of the black-white sentencing disparity that was not otherwise explained by precharge characteristics. This is perhaps not surprising given the very large unexplained racial disparity in the rate at which mandatory minimum charges are brought (see table 2, col. 2). Still, the effect is striking given our conservative method of coding ambiguous charges. Many federal charges do not carry mandatory minimums unless specific factual circumstances are present. When there was any uncertainty about whether an initial charge carried a mandatory minimum sentence, we assumed that it did not carry one. Thus, our initial mandatory minimum charge variable underestimates the true prevalence of such charges. The extent of this underestimation cannot be directly measured with the initial charge data. Data on final charges suggest that it is not trivial. Our coding identifies 7.5 percent of

\footnotetext{
${ }^{34}$ This is also true if one uses alternative measures of charge severity, based either on the guidelines sentence for the initial charge or on past actual mean sentences for the charges in question. Neither measure had additional explanatory power when the mandatory minimum was included, although each had some explanatory power on its own.
} 
cases as including a final charge that carries a mandatory minimum, while the USSC data (which are error free) indicate that 14.7 percent of cases contain such a charge. If a similar error rate also applies to our identification of initial charges carrying mandatory minimums, the true mandatory minimum rate in initial charges could be approximately 22 percent rather than the 11.4 percent that we observe.

All else equal, the presence of a mandatory minimum is positively correlated with both sentence length and being black. ${ }^{35}$ Therefore, the error in the mandatory minimum variable will create upward bias in the coefficient of interest, the remaining unexplained racial disparity. Estimates using data on final mandatory minimums confirm the direction of this bias and are suggestive of its likely magnitude. Rows 4 and 5 of table 5 replace our mandatory minimum initial charge indicator with indicators of the final mandatory minimum based on our coding of the conviction data (row 4) and the USSC's recording of the mandatory minimum. The estimated racial disparity in sentences is marginally larger but statistically indistinguishable when our coding of a mandatory minimum initial charge is replaced with our coding of a mandatory minimum charge being present at conviction (row 4). In contrast, when the USSC's coding of the final mandatory minimum is used (row 5), the black coefficient is reduced to a statistically insignificant 3 percent at the median and is close to zero or even negative at the top three deciles. This suggests that our conservative coding leads us to underestimate mandatory minimums' role in explaining sentencing disparity; mandatory minimums may in fact be capable of explaining nearly all of the otherwiseunexplained black-white sentence gap. ${ }^{36}$

\section{E. Drug and Child Pornography Cases}

The main analyses exclude drug and child pornography cases, which are a large component of the federal docket. We reestimate our main

${ }^{35}$ This is true for our coding of mandatory minimums, and the USSC data indicate that it is also true for the mandatory minimums that our coding misses.

${ }^{36}$ Formally deriving bounds for the OLS estimate of the black coefficient (table A1) given the errors in our identification of initial charges carrying mandatory minimums leads to a similar conclusion. The general bounds on the black coefficient are given by $\gamma_{b}-\left(\delta_{b} / b^{r}\right)$ and $\gamma_{b}-\delta_{b} b^{d}$ (Klepper and Leamer 1984; Klepper 1988; Erikson 1993; Bollinger 1996), where $\gamma_{b}$ is the black coefficient from the regression of sentences on all the controls except the initial mandatory minimum indicator (table A1, col. 4), and $\delta_{b}$ is the black coefficient from the regression of the initial mandatory minimum charge indicator on all the controls $(0.052)$. The variables $b^{d}$ and $b^{r}$ are, respectively, the coefficients from the direct and reverse regressions of the residuals from the separate linear projections of sentences on all the controls except mandatory minimum charging and the mandatory minimum initial charge indicator on all the other controls (60.15 and 0.0015). The resulting bounds on the black coefficient are -27.6 to 3.8 months. Working with the upper bound, if one assumes that the correlation between the mismeasured and true mandatory minimum indicator is the same as the correlation between the two measures at final charges $(\rho=.6358)$, then it would be further 
analyses on a sample expanded to include drug and child pornography cases (table 6, row 1). The pattern of racial disparity is similar to that found in the main estimation. The black coefficient appears to be slightly larger in these cases (11-13 percent), but this could be due to arrest offense being a weaker proxy for the severity of underlying criminal behavior in the absence of information on drug quantity at arrest. ${ }^{37}$ In order to see whether prosecutors' charging decisions are also capable of explaining racial disparity in this broader sample, we again add the presence of charges carrying mandatory minimums as a control. Because the AOUSC charge data are inadequate to determine whether the initial drug or child pornography charge carried a mandatory minimum sentence, we instead use an indicator for the USSC's recording of whether the final charge did. When this indicator is included in the estimation, the unexplained racial disparity is substantially reduced to between 4 and 7 percent. This suggests that disparities in mandatory minimum charging are an important contributor to racial disparity in sentences in these cases as well. ${ }^{38}$

\section{Discussion}

The estimates presented above document substantial racial disparity in federal criminal sentences, across the sentence distribution and across a wide variety of samples and specifications. Furthermore, the way prosecutors choose to charge cases appears to be an important factor in these

reduced to $\gamma_{b}-\delta_{b}\left(b^{d} / \rho\right)$, which is 2 months (the estimated disparity at the median conditional on the USSC indicator, table 5 , row 5 , corresponds to 1.95 months).

${ }_{37}$ The EOUSA investigation file records the type and quantity of drugs seized at arrest. Unfortunately, there are serious defects in the quantity field beginning in 2004. But for the last three years in which quantity information is available, fiscal years 2001-3, there is no racial disparity in the average quantity seized (as measured in "marijuana equivalents" as defined by federal sentencing law), conditional on arrest offense and other prearrest covariates, and adding quantity information to the arrest offense controls does not significantly change the racial disparity estimates for sentences in that period. Arrest quantity differences thus would likely explain the estimated racial disparities in table 6 only if black arrestees' distribution of quantities grew substantially relative to those of white arrestees between that period and fiscal years 2006-8, the years of our sample.

${ }^{38}$ A similar pattern emerges if one instead limits the estimates to drug and child pornography cases alone. Across the deciles the overall estimate of racial disparity ranges from 10 to 15 percent, and the inclusion of a control for the presence of a mandatory minimum charge at sentencing reduces the estimated disparity by approximately one-third. The remaining racial disparity after controlling for the mandatory minimum is larger in the drug and child pornography sample. The reason may be partly that in drug cases, the mere existence of a mandatory minimum does not capture as much of the important charging variation: most drug defendants face some mandatory minimum, so the most important factor may be the length of that minimum. Replacing the mandatory minimum indicator with a categorical variable that differentiates mandatory minimums by length further cuts the remaining unexplained disparities by nearly half. In contrast, substituting the categorical version for the indicator has little effect on the results for the main sample. 
TABLE 6

Black-White log Sentence Disparity: All Case Types

Including Drugs and Child Pornography

\begin{tabular}{lllllll}
\hline \hline & Q40 & Q50 & Q60 & Q70 & Q80 & Q90 \\
\hline Main specification (table 3, row 4) & $.132^{* * *}$ & $.127^{* *}$ & $.121^{* *}$ & $.117^{* *}$ & $.113^{* *}$ & $.114^{* *}$ \\
& {$[.020]$} & {$[.019]$} & {$[.016]$} & {$[.016]$} & {$[.015]$} & {$[.015]$} \\
With mandatory minimum present & & & & & & \\
$\quad \begin{array}{l}\text { at sentencing indicator } \\
\quad \text { (USSC measure) }\end{array}$ & $.070^{* *}$ & $.066^{* *}$ & $.062^{* *}$ & $.053^{* *}$ & $.048^{* *}$ & $.042^{* *}$ \\
& {$[.018]$} & {$[.018]$} & {$[.017]$} & {$[.014]$} & {$[.013]$} & {$[.014]$} \\
\hline
\end{tabular}

Note. $-N=71,698$. Each cell contains the coefficient on black from a separate quantile regression. The point estimate is the median point estimate across the 15 hot deck imputations of criminal history and education. Standard errors block bootstrapped by district are in brackets.

+ Significant at the 10 percent level.

* Significant at the 5 percent level.

** Significant at the 1 percent level.

disparities. The findings concerning mandatory minimums' sentencing consequences are particularly striking given that such charges, according to our coding, are brought in only 11.4 percent of cases in our main sample (and only 16.4 percent of black defendants' cases). It is notable that disparities within a type of charge that does not apply to most cases could explain such a large fraction of the otherwise-unexplained disparities in the total pool. However, the unexplained disparities that we measure (as well as the contribution of prosecutorial decisions to those disparities) are open to competing interpretations, and we consider some leading alternatives here.

First, while the arrest offense is the best proxy available for the defendant's actual criminal conduct, it is naturally an imperfect proxy. Between the detailed arrest codes, the multidefendant flag, and the written description based on the arresting officer's notes, the information on arrest is fairly rich, and the results also do not appear to be driven by any particular arresting agency's cases. But there could still be factual differences that are not captured by the arrest codes or by the written description: like prosecutors, officers could choose to describe the same facts in different ways, and if they do so along racial lines, that divergence could bias racial disparity estimates that are conditioned on the arrest data. ${ }^{39}$

However, the existing literature on law enforcement suggests that the direction of any bias introduced by arrest discretion is likely downward. Studies in numerous contexts have pointed to the possibility of police

\footnotetext{
${ }^{39}$ For example, if police are sympathetic to black arrestees (or believe that prosecutors and judges treat them too harshly) and soften their arrest reports accordingly, then prosecutors could appear to charge black defendants more harshly conditional on arrest offense but be charging them equally conditional on true criminal behavior.
} 
bias against minority suspects (e.g., Gelman, Fagan, and Kiss 2007), although there is considerable debate as to whether these are driven by statistical or preference-based discrimination (e.g., Knowles, Persico, and Todd 2001; Antonovics and Knight 2009). If federal agents are harsher on black suspects, one would expect them to record, on average, more offenses for blacks relative to their true conduct and to up-code offenses whenever possible. Then, prosecutors' cases against black defendants, conditional on arrest offense, should be weaker, and the estimated results may understate the "true" race gaps in charging (or at least are unlikely to overstate them). ${ }^{40}$

Another possibility is that race is correlated with unobserved characteristics of the defendant (rather than the case) that influence prosecutorial choices. Candidates include poverty and, relatedly, defense counsel quality. But the inclusion of counsel type and other socioeconomic controls (education, marital status, and county characteristics) does not reduce the estimates of racial disparity in charging or sentencing. This is less surprising than it may appear, given the high quality of federal public defenders (see Posner and Yoon 2011). ${ }^{41}$

While other unobserved differences cannot be ruled out, there remains the possibility that the observed disparities are driven by discrimination, which could be either statistical or preference based. The mechanism for preference-based discrimination might well be implicit biases such as racial disparities in empathy that drive selective leniency rather than animus. Statistical discrimination might, for instance, be based on expectations concerning criminal recidivism (see Curry and Klumpp 2009). One might, however, expect the effect of beliefs about these nonrace factors and their correlation with race to vary across the conditional distribution rather than produce the surprisingly stable race parameter we document.

Preference-based and statistical discrimination cannot be conclusively disentangled using these data. Notably, however, if any form of purposeful race-based decision making is involved, none of these mechanisms are legally permissible. Otherwise-unconstitutional discrimination cannot be legally defended on the basis of statistical generalizations about group traits, regardless of their empirical support (J.E.B. v. Alabama ex rel T.B., 511 U.S. 127 1994). In addition, statistically discriminating prosecutors may not have the opportunity to modify charges as

\footnotetext{
${ }^{40}$ While the conclusions of the policing studies vary, they at least do not generally suggest discrimination favoring blacks. One cannot rule out the possibility that the reverse pattern holds within the sample; federal agents may differ from the state and local police generally studied in the policing literature. But the results at the charging and sentencing stages do not, at least, appear driven by any particular enforcement agencies' patterns.

${ }^{41}$ In contrast, in state courts that have less effective public defender programs, any racial disparities might be expected to be compounded by socioeconomic disparities.
} 
they update their initial beliefs about the individual or case, as employers can do in the labor market (Altonji and Pierret 2001). Criminal cases are often processed quickly, with little chance for personal interaction between prosecutors and defendants, and because Department of Justice policy discourages charge bargaining and requires the approval of a supervisor to reduce charges in plea agreements, it may be costly or difficult for prosecutors to change charges even if they do update their beliefs.

Finally, these disparity estimates do not include structural inequality. For example, they do not include the racial disparity in sentences due to black arrestees being more likely to live in federal districts that give higher sentences or be arrested for crimes that are associated with longer sentences. Both could exist for numerous reasons unrelated to race. However, it is also possible that the racial makeup of arrestees directly affects how punitive the justice system is in particular districts or the relative statutory penalties for offenses. Likewise, the choice to weigh criminal history heavily in the guidelines sentencing scheme, while grounded in a variety of policy considerations, has a substantial disparate impact on black defendants.

\section{Conclusion}

Using rich new linked data that allow us to address the sample selection problems and other limitations that have pervaded prior research, this paper provides robust evidence that black male federal arrestees ultimately face longer prison terms than whites arrested for the same offenses with the same prior records. This disparity arises from disparities in the intensive but not in the extensive margin of incarceration. Observed case and defendant characteristics are capable of completely explaining the large raw disparities in incarceration, but not in the length of incarceration. The conditional black-white sentence disparity is approximately 9 percent at each decile in our main sample. ${ }^{42}$ If the disparity is 9 percent across the entire conditional distribution of these cases, then the conditional mean effect of race is also approximately 9 percent. ${ }^{43}$

There are currently 95,400 black men incarcerated in federal facilities. Eliminating a 9 percent black premium would ultimately reduce the steady-state number of black males in federal incarceration by nearly 8,000 , and most of this reduction could potentially be achieved by simply

\footnotetext{
${ }^{42}$ Owing to the aforementioned limitations of the drug case arrest offense data, the estimates from the sample excluding drugs are our preferred estimates. They are also the most conservative.

${ }^{43}$ The estimate from the median regression will also be a consistent estimator of the conditional mean effect if the conditional sentence distribution is symmetric.
} 
eliminating the disparity in mandatory minimum charges. ${ }^{44}$ To place this number in the context of recent reforms, when the US Sentencing Commission retroactively applied the Fair Sentencing Act of 2010 (which reduced the disparity in the treatment of crack vs. powder cocaine), it shortened the sentences of 7,381 men and women of all races (US Sentencing Commission 2013). The Bureau of Prisons estimates that it costs $\$ 29,027$ per year to incarcerate an additional prisoner (Congressional Research Service 2013). The direct federal budgetary savings of reducing the prison stock by 8,000 men would be approximately $\$ 230$ million per year. These calculations are likely conservative because they apply the smaller disparity estimate from the main (nondrug) sample to all case types. If the disparity in sentences is instead the larger estimated disparity for all case types, 12.7 percent at the median (table 6), then eliminating it would reduce the steady-state number of black men in federal prison by almost 11,000. Furthermore, the rapidly growing prison population (US General Accounting Office 2013) means that the number of individuals expected to be affected by these disparities will only grow over time. Finally, all these estimates exclude any structural disparities that could themselves be partly due to race.

In the federal system, more than half of the black-white sentence disparity that is unexplained by the arrest offense and offenders' prior traits can be explained by initial charge decisions, particularly the prosecutors' decision to file charges that carry "mandatory minimum" sentences. Ceteris paribus, they do so 65 percent more often against black defendants. These findings highlight the empirical importance of obtaining measures of criminal conduct that are not themselves the product of the legal process. They also suggest that recent policy and scholarly debates that have focused heavily on the disparity risks associated with judicial discretion may have overlooked one of the most important actors: the federal prosecutor.

Moreover, while our findings concern only the federal system, our approach could be employed in future research in state settings if arrest, charging, and sentencing data can be linked. The size of racial disparities and the role of mandatory minimums at the state level are important

\footnotetext{
${ }^{44}$ This calculation is based on a reduction in black male prison stocks to $1 / 1.09$ of their current level. As of November 2013, there are approximately 73,000 black male inmates incarcerated in federal Bureau of Prisons facilities (78,241 black prisoners, 93.3 percent of whom are male; see http://www.bop.gov/news/quick.jsp). In addition, the Federal Detention Program administered by the US Marshals' Service has approximately 22,400 black male detainees (assuming race and gender breakdown parallel to the Bureau of Prisons'; see http://www.justice.gov/jmd/2013justification/pdf/fyl3-fpd-justification.pdf). Reducing this 95,400 black male prisoner stock to $1 / 1.09$ of its current level would free approximately 7,900 prisoners. The estimates here represent the per-year benefits of changes that are sustained over sufficient time to affect the sentences of all persons in prison; or, conversely, it represents the counterfactual reduction in current prison stocks if current black male prisoners had received sentences averaging 1/1.09 of their actual lengths.
} 
areas for future research. Mandatory minimums exist in every state (Stemen, Rengifo, and Wilson 2006; Tonry 2011) and are often described as a major contributor to the fivefold growth in US incarceration rates since the 1970s (Clear and Austin 2009; Blumstein 2011). If similar unexplained racial disparities in sentence outcomes exist in state systems, which process over 90 percent of criminal cases, eliminating them would have social and budgetary consequences that are approximately 10 times as large as those in the federal system. One out of every nine black men between the ages of 18 and 35 is currently incarcerated (Pew Center on the States 2008). If one assumes that all black male sentences in federal and state court face an average race premium of 9 percent, eliminating this disparity would ultimately move nearly 1 percent of all the black men under 35 in the United States from prisons and jails back to the community.

\section{Appendix}

TABLE A1

OLS Regressions of Prison Sentence Length (Months)

\begin{tabular}{|c|c|c|c|c|c|c|c|}
\hline & (1) & (2) & (3) & (4) & (5) & (6) & (7) \\
\hline Black & $\begin{array}{c}26.80^{* *} \\
{[2.401]}\end{array}$ & $\begin{array}{c}14.54 * * \\
{[1.773]}\end{array}$ & $\begin{array}{l}9.615^{* *} \\
{[1.617]}\end{array}$ & $\begin{array}{l}6.920^{* *} \\
{[1.016]}\end{array}$ & $\begin{array}{c}3.846^{* *} \\
{[.972]}\end{array}$ & $\begin{array}{l}3.923 * * \\
{[.907]}\end{array}$ & $\begin{array}{l}1.315 \\
.883\end{array}$ \\
\hline Multidefendant & & $\begin{array}{l}7.631 * * \\
{[1.587]}\end{array}$ & $\begin{array}{l}9.464^{* *} \\
{[1.524]}\end{array}$ & $\begin{array}{l}8.599 * * \\
{[1.305]}\end{array}$ & $\begin{array}{l}5.115^{* *} \\
{[1.220]}\end{array}$ & $\begin{array}{l}5.596^{* *} \\
{[1.157]}\end{array}$ & $\begin{array}{l}3.774^{* * *} \\
{[1.024]}\end{array}$ \\
\hline $\begin{array}{l}\text { Criminal } \\
\text { history } 2\end{array}$ & & & $\begin{array}{c}3.565^{*} \\
{[1.240]}\end{array}$ & $\begin{array}{l}4.596^{* *} \\
{[1.225]}\end{array}$ & $\begin{array}{c}2.963^{+} \\
{[1.264]}\end{array}$ & $\begin{array}{c}3.280 * \\
{[1.164]}\end{array}$ & $\begin{array}{l}3.146 * \\
{[1.032]}\end{array}$ \\
\hline $\begin{array}{l}\text { Criminal } \\
\text { history } 3\end{array}$ & & & $\begin{array}{l}7.498^{* *} \\
{[1.115]}\end{array}$ & $\begin{array}{l}8.117 * * \\
{[1.067]}\end{array}$ & $\begin{array}{l}7.860 * * \\
{[.927]}\end{array}$ & $\begin{array}{l}7.932 * * \\
{[.894]}\end{array}$ & $\begin{array}{c}8.142 * * \\
{[.890]}\end{array}$ \\
\hline $\begin{array}{l}\text { Criminal } \\
\text { history } 4\end{array}$ & & & $\begin{array}{c}21.87 * * \\
{[1.392]}\end{array}$ & $\begin{array}{c}21.64 * * \\
{[1.276]}\end{array}$ & $\begin{array}{c}22.17 * * \\
{[1.319]}\end{array}$ & $\begin{array}{c}22.35 * * \\
{[1.271]}\end{array}$ & $\begin{array}{c}19.46 * * \\
{[1.062]}\end{array}$ \\
\hline $\begin{array}{l}\text { Criminal } \\
\text { history } 5\end{array}$ & & & $\begin{array}{c}29.14 * * \\
{[1.393]}\end{array}$ & $\begin{array}{c}29.70 * * \\
{[1.300]}\end{array}$ & $\begin{array}{c}30.21 * * \\
{[1.369]}\end{array}$ & $\begin{array}{c}30.83^{* *} \\
{[1.348]}\end{array}$ & $\begin{array}{c}28.56^{* * *} \\
{[1.284]}\end{array}$ \\
\hline $\begin{array}{l}\text { Criminal } \\
\text { history } 6\end{array}$ & & & $\begin{array}{c}61.87 * * \\
{[2.527]}\end{array}$ & $\begin{array}{c}61.34 * * \\
{[2.526]}\end{array}$ & $\begin{array}{c}59.82 * * \\
{[2.526]}\end{array}$ & $\begin{array}{c}60.50 * * \\
{[2.606]}\end{array}$ & $\begin{array}{c}49.59 * * \\
{[1.687]}\end{array}$ \\
\hline $\begin{array}{l}\text { Mandatory } \\
\text { minimum } \\
\text { initial charge }\end{array}$ & & & & & $\begin{array}{c}60.15^{* * *} \\
{[2.717]}\end{array}$ & & \\
\hline $\begin{array}{l}\text { Mandatory } \\
\text { minimum } \\
\text { conviction }\end{array}$ & & & & & & $\begin{array}{c}85.73 * * \\
{[3.303]}\end{array}$ & \\
\hline
\end{tabular}


TABLE A1 (Continued)

\begin{tabular}{|c|c|c|c|c|c|c|c|}
\hline & (1) & (2) & (3) & (4) & (5) & (6) & (7) \\
\hline $\begin{array}{l}\text { Statutory } \\
\text { minimum } \\
\text { present at } \\
\text { sentencing }\end{array}$ & & & & & & & $\begin{array}{l}97.00^{* * *} \\
{[2.612]}\end{array}$ \\
\hline Constant & $\begin{array}{c}38.09 * * \\
{[1.251]}\end{array}$ & $\begin{array}{c}185.1 * * \\
{[66.21]}\end{array}$ & $\begin{array}{c}153.9 * \\
{[66.00]}\end{array}$ & $\begin{array}{l}151.2^{*} \\
{[62.27]}\end{array}$ & $\begin{array}{l}108.4 \\
{[60.34]}\end{array}$ & $\begin{array}{c}118.0^{*} \\
{[53.00]}\end{array}$ & $\begin{array}{l}115.2^{*} \\
{[50.98]}\end{array}$ \\
\hline $\begin{array}{l}\text { Arrest offense? } \\
\text { Age and }\end{array}$ & & Yes & Yes & Yes & Yes & Yes & Yes \\
\hline $\begin{array}{l}\text { education? } \\
\text { District? }\end{array}$ & & & & Yes & Yes & $\begin{array}{l}\text { Yes } \\
\text { Yes }\end{array}$ & $\begin{array}{l}\text { Yes } \\
\text { Yes }\end{array}$ \\
\hline
\end{tabular}

Note. $-N=36,659$. Incarceration sentences are 0 months for all uncharged or nonconvicted defendants as well as those convicted but sentenced to zero incarceration. Point estimates in cols. 3-7 are from the hot deck imputation of criminal history and education that produces the median estimate of the black coefficient across the 15 hot deck imputations. Standard errors clustered by district are in brackets.

+ Significant at the 10 percent level.

* Significant at the 5 percent level.

** Significant at the 1 percent level.

\section{References}

$\rightarrow$ Altonji, J. G., and C. R. Pierret. 2001. "Employer Learning and Statistical Discrimination." Q.J.E. 116 (1): 313-50.

$\rightarrow$ Andridge, R., and R. Little. 2010. "A Review of Hot Deck Imputation for Survey Non-response.” Internat. Statis. Rev. 78 (1): 40-64.

Angrist, J., E. Bettinger, and M. Kremer. 2006. "Long-Term Educational Consequences of Secondary School Vouchers: Evidence from Administrative Records in Colombia." A.E.R. 96 (3): 847-62.

$\rightarrow$ Antonovics, K., and B. G. Knight. 2009. "A New Look at Racial Profiling: Evidence from the Boston Police Department." Rev. Econ. and Statis. 91:163-77.

Ashcroft, J. 2003. "Department Policy Concerning Charging Offenses, Disposition of Charges, and Sentencing." Memorandum (September 22), US Dept. Justice, Washington, DC.

$\rightarrow$ Baker, S., and C. Mezzetti. 2001. "Prosecutorial Resources, Plea Bargaining, and the Decision to Go to Trial." J. Law, Econ., and Org. 17:149-67.

$\rightarrow$ Bjerk, D. 2005. "Making the Crime Fit the Penalty: The Role of Prosecutorial Discretion under Mandatory Minimum Sentencing." J. Law and Econ. 48:591-625.

Bloomfield, P., and W. Steiger. 1983. Least Absolute Deviations: Theory, Applications and Algorithms. Boston: Birkhauser.

Blumstein, A. 2011. "Bringing Down the U.S. Prison Population." Prison J. 91 (3): 12S-26S.

$\rightarrow$ Bollinger, C. R. 1996. "Bounding Mean Regressions When a Binary Regressor Is Mismeasured." J. Econometrics 73 (2): 387-99.

Bonczar, T. P. 2003. Prevalence of Imprisonment in the U.S. Population, 1974-2001. Washington, DC: US Dept. Justice. http://www.bjs.gov/content/pub/pdf/piusp01 .pdf.

$\rightarrow$ Bushway, S., E. Owens, and A. Piehl. 2012. "Sentencing Guidelines and Judicial Discretion: Quasi-experimental Evidence from Human Calculation Errors." J. Empirical Legal Studies 9 (2): 291-319. 
Carson, E. A., and W. J. Sabol. 2012. Prisoners in 2011. NCJ 239808. Washington, DC: US Dept. Justice, Bur. Justice Statis.

Clear, T. R., and J. Austin. 2009. "Reducing Mass Incarceration: Implications of the Iron Law of Prison Populations." Harvard Law and Policy Rev. 3:307-24.

Congressional Research Service. 2013. The Federal Prison Population Buildup: Overview, Policy Changes, Issues, and Options. Report 7-5700. Washington, DC: Congressional Res. Service.

$\rightarrow$ Curry, P., and T. Klumpp. 2009. "Crime, Punishment, and Prejudice." J. Public Econ. 93:73-84.

$\rightarrow$ Easterbrook, F. H. 1983. "Criminal Procedure as a Market System.” J. Legal Studies 12:289-332.

Erikson, T. 1993. "Restricting Regression Slopes in the Errors-in-Variables Model by Bounding the Error Correlation." Econometrica 61 (4): 959-69.

$\rightarrow$ Fischman, J. B., and M. M. Schanzenbach. 2012. "Racial Disparities under the Federal Sentencing Guidelines: The Role of Judicial Discretion and Mandatory Minimums." J. Empirical Legal Studies 9:729-64.

Fong, C. M., and E. F. P. Luttmer. 2009. "What Determines Giving to Hurricane Katrina Victims? Experimental Evidence on Racial Group Loyalty." American Econ. J.: Appl. 1 (2): 64-87.

$\rightarrow$ Gelman, A., J. Fagan, and A. Kiss. 2007. "Analysis of the New York City Police Department's 'Stop-and-Frisk' Policy in the Context of Claims of Racial Bias." J. American Statis. Assoc. 102:813-23.

$\rightarrow$ Gilbert, Scott A., and M. T. Johnson. 1996. "The Federal Judicial Center's 1996 Survey of Judicial Experience." Fed. Sentencing Rev. 9:87-93.

$\rightarrow$ Glaeser, E. L., D. P. Kessler, and A. M. Piehl. 2000. "What Do Prosecutors Maximize?" American Law and Econ. Rev. 13 (2): 259-90.

Goette, L., D. Huffman, and S. Meier. 2006. "The Impact of Group Membership on Cooperation and Norm Enforcement: Evidence Using Random Assignment to Real Social Groups." A.E.R. 96 (2): 212-16.

Johnson, W., Y. Kitamura, and D. Neal. 2000. "Evaluating a Simple Method for Estimating Black-White Gaps in Median Wages." A.E.R. 90 (2): 339-43.

$\rightarrow$ Kessler, D. P., and A. M. Piehl. 1998. "The Role of Discretion in the Criminal Justice System.” J. Law, Econ., and Org. 14:256-76.

$\rightarrow$ Klepper, S. 1988. "Bounding the Effects of Measurement Error in Regressions Involving Dichotomous Variables." J. Econometrics 37:343-59.

$\rightarrow$ Klepper, S., and E. Leamer. 1984. "Consistent Sets of Estimates for Regressions with Errors in All Variables." Econometrica 52 (1): 163-84.

$\rightarrow$ Knowles, J., N. Persico, and P. Todd. 2001. "Racial Bias in Motor Vehicle Searches." J.P.E. 109 (1): 203-29.

$\rightarrow$ Landes, W. M. 1971. "An Economic Analysis of the Courts." J. Law and Econ. 14:61-108.

Linder, D. O. 1996. “Juror Empathy and Race.” Tennessee Law Rev. 63:887-916.

$\rightarrow$ Miethe, T. D. 1987. "Charging and Plea Bargaining Practices under Determinate Sentencing." J. Criminal Law and Criminology 78:155-76.

$\rightarrow$ Miller, M. L. 2004. "Domination and Dissatisfaction: Prosecutors as Sentencers." Stanford Law Rev. 56:1211-76.

$\rightarrow$ Mustard, D. B. 2001. "Racial, Ethnic and Gender Disparities in Sentencing: Evidence from the U.S. Federal Courts." J. Law and Econ. 44:285-314.

Nowacki, J. S. 2013. "Race, Ethnicity, and Judicial Discretion: The Influence of the United States v. Booker Decision." Crime and Delinquency. Electronically published January 16.

Pew Center on the States. 2008. One in 100: Behind Bars in America, 2008. http:// www.pewstates.org/uploadedFiles/PCS_Assets/2008/one\%20in\%20100.pdf. 
Posner, R. A., and A. H. Yoon. 2011. "What Judges Think of the Quality of Legal Representation." Stanford Law Rev. 63:317-50.

$\rightarrow$ Powell, J. 1986. "Censored Regression Quantiles." J. Econometrics 32 (1): 143-55.

Schulhofer, S. J., and I. Nagel. 1997. "Plea Negotiations under the Federal Sentencing Guidelines.” Northwestern Univ. Law Rev. 91:1284-1316.

Scott, R. W. 2010. "Inter-judge Sentencing Disparity after Booker: A First Look." Stanford Law Rev. 63 (1): 1-66.

$\rightarrow$ Shermer, L. O., and B. D. Johnson. 2010. "Criminal Prosecutions: Examining Prosecutorial Discretion and Charge Reductions in U.S. Federal District Courts." Justice Q. 27:394-95.

Skolnik, S. 1999. "Grand Jury: Power Shift?” Legal Times, April 12.

Starr, S. B. 2012. "Gender Disparity in Federal Criminal Cases." Law and Economics Research Paper no. 12-018, Univ. Michigan.

Stemen, D., A. F. Rengifo, and J. Wilson. 2006. "Of Fragmentation and Ferment: The Impact of State Sentencing Policies on Incarceration Rates, 1975-2002." Manuscript, Dept. Justice, Washington, DC.

$\rightarrow$ Stith, K. 2008. "The Arc of the Pendulum: Judges, Prosecutors, and the Exercise of Discretion." Yale Law J. 117:1420-97.

Tonry, M. 2011. "Crime and Criminal Justice." In The Oxford Handbook of Crime and Criminal Justice, edited by M. Tonry. Oxford: Oxford Univ. Press.

$\rightarrow$ Ulmer, J. T., M. T. Light, and J. H. Kramer. 2011. "Racial Disparity in the Wake of the Booker/Fanfan Decision: An Alternative Analysis to the USSC's 2010 Report." Criminology and Public Policy 10:1077-1118.

US General Accounting Office. 2013. Bureau of Prisons: Opportunities Exist to Enhance the Transparency of Annual Budget Justifications. Publication no. GAO-14121. Washington, DC: US General Accounting Office.

US Sentencing Commission. 2010. Demographic Differences in Federal Sentencing Practices. Washington, DC: US Sentencing Comm.

. 2011. Report to Congress: Mandatory Minimum Penalties in the Federal Criminal Justice System. Washington, DC: US Sentencing Comm.

. 2012. Report on the Continuing Impact of United States v. Booker on Federal Sentencing. Washington, DC: US Sentencing Comm.

- 2013. Preliminary Crack Retroactivity Data Report. Washington, DC: US Sentencing Comm.

Warner, M. C. 2004. "The Trials and Tribulations of Petty Offenses in the Federal Courts." New York Univ. Law Rev. 79:2417-49. 